\title{
Facility level measurement of offshore oil and gas installations from a medium-sized airborne platform: method development for quantification and source identification of methane emissions
}

\author{
James L. France ${ }^{1,2}$, Prudence Bateson ${ }^{3}$, Pamela Dominutti ${ }^{4}$, Grant Allen ${ }^{3}$, Stephen Andrews ${ }^{4}$, Stephane Bauguitte ${ }^{5}$, \\ Max Coleman ${ }^{2,10}$, Tom Lachlan-Cope ${ }^{1}$, Rebecca E. Fisher ${ }^{2}$, Langwen Huang ${ }^{3,9}$, Anna E. Jones ${ }^{1}$, James Lee ${ }^{6}$, \\ David Lowry ${ }^{2}$, Joseph Pitt ${ }^{3,8}$, Ruth Purvis ${ }^{6}$, John Pyle ${ }^{7,11}$, Jacob Shaw ${ }^{3}$, Nicola Warwick ${ }^{7,11}$, Alexandra Weiss ${ }^{1}$, \\ Shona Wilde ${ }^{4}$, Jonathan Witherstone ${ }^{1}$, and Stuart Young ${ }^{4}$ \\ ${ }^{1}$ British Antarctic Survey, Natural Environment Research Council, Cambridge CB3 0ET, UK \\ ${ }^{2}$ Department of Earth Sciences, Royal Holloway, University of London, Egham TW20 0EX, UK \\ ${ }^{3}$ Department of Earth and Environmental Science, University of Manchester, Manchester, M13 9L, UK \\ ${ }^{4}$ Wolfson Atmospheric Chemistry Laboratories, Department of Chemistry, University of York, Heslington, YO10 5DD, UK \\ ${ }^{5}$ FAAM Airborne Laboratory, National Centre for Atmospheric Science, Cranfield, MK43 0AL, UK \\ ${ }^{6}$ National Centre for Atmospheric Science, University of York, York, YO10 5DQ, UK \\ ${ }^{7}$ Department of Chemistry, University of Cambridge, Cambridge, CB2 1EW, UK \\ ${ }^{8}$ School of Marine and Atmospheric Sciences, Stony Brook University, Stony Brook, NY 11974, USA \\ ${ }^{9}$ Departement Mathematik, ETH Zurich, Rämistrasse 101, 8092 Zurich, Switzerland \\ ${ }^{10}$ Department of Meteorology, University of Reading, Reading, RG6 6BB, UK \\ ${ }^{11}$ National Centre for Atmospheric Science (NCAS), University of Cambridge, Cambridge, UK
}

Correspondence: James L. France (james.france@rhul.ac.uk)

Received: 28 April 2020 - Discussion started: 2 July 2020

Revised: 4 November 2020 - Accepted: 4 November 2020 - Published: 5 January 2021

\begin{abstract}
Emissions of methane $\left(\mathrm{CH}_{4}\right)$ from offshore oil and gas installations are poorly ground-truthed, and quantification relies heavily on the use of emission factors and activity data. As part of the United Nations Climate \& Clean Air Coalition (UN CCAC) objective to study and reduce shortlived climate pollutants (SLCPs), a Twin Otter aircraft was used to survey $\mathrm{CH}_{4}$ emissions from UK and Dutch offshore oil and gas installations. The aims of the surveys were to (i) identify installations that are significant $\mathrm{CH}_{4}$ emitters, (ii) separate installation emissions from other emissions using carbon-isotopic fingerprinting and other chemical proxies, (iii) estimate $\mathrm{CH}_{4}$ emission rates, and (iv) improve flux estimation (and sampling) methodologies for rapid quantification of major gas leaks.

In this paper, we detail the instrument and aircraft setup for two campaigns flown in the springs of 2018 and 2019 over the southern North Sea and describe the developments made in both the planning and sampling methodol-
\end{abstract}

ogy to maximise the quality and value of the data collected. We present example data collected from both campaigns to demonstrate the challenges encountered during offshore surveys, focussing on the complex meteorology of the marine boundary layer and sampling discrete plumes from an airborne platform. The uncertainties of $\mathrm{CH}_{4}$ flux calculations from measurements under varying boundary layer conditions are considered, as well as recommendations for attribution of sources through either spot sampling for volatile organic compounds (VOCs) $/ \delta^{13} \mathrm{C}_{\mathrm{CH} 4}$ or using in situ instrumental data to determine $\mathrm{C}_{2} \mathrm{H}_{6}-\mathrm{CH}_{4}$ ratios. A series of recommendations for both planning and measurement techniques for future offshore work within marine boundary layers is provided. 


\section{Overview}

Methane is a potent greenhouse gas in the atmosphere, with a global warming potential 84 times that of carbon dioxide when calculated over a 20-year period (Myhre et al., 2013). Increases in atmospheric $\mathrm{CH}_{4}$ mixing ratios are expected to have major influences on Earth's climate, and emission mitigation could go some way toward achieving goals laid out in the UNFCCC (United Nations Framework Convention on Climate Change) Paris Agreement (Nisbet et al., 2019).

Offshore oil and gas fields make up $\sim 28 \%$ of total global oil and gas production and are expected to be significant sources of $\mathrm{CH}_{4}$ to the atmosphere, given that $22 \%$ of global $\mathrm{CH}_{4}$ emissions are estimated to be from the oil and gas $(O \& G)$ sector (Saunois et al., 2016). Some emissions arise from routine operations or minor engineering failures (Zavala-Araiza et al., 2017), while others stem from large unexpected leaks (e.g. Conley et al., 2016; Ryerson et al., 2012). In some O\&G fields, large amounts of nonrecoverable $\mathrm{CH}_{4}$ can be flared or vented due to a number of factors. Thus, the composition of O\&G emissions can be influenced by several variables, including the targeted hydrocarbon product (oil or gas), extraction techniques and gas capture infrastructure. O\&G installations co-emit volatile organic compounds (VOCs) such as alkanes, alkenes and aromatics in addition to $\mathrm{CH}_{4}$. Some of these VOCs are toxic and can have direct health impacts or, together with $\mathrm{NO}_{x}$, can produce ozone, having an impact on the regional air quality (Edwards et al., 2013). VOC and $\delta^{13} \mathrm{C}_{\mathrm{CH} 4}$ measurements can be utilised to fingerprint the main processes or likely location responsible for associated $\mathrm{CH}_{4}$ emissions (CardosoSaldaña et al., 2019; Lee et al., 2018; Yacovitch et al., 2014a). A recent study has also demonstrated the cost-effectiveness of airborne measurements for leak detection and repair at O\&G facilities relative to traditional ground-based methods (Schwietzke et al., 2019).

There is thus a need to develop reliable methodologies to locate emissions, determine sources in sufficient detail to allow for the quantification of emissions and validate against publicly reported inventory emissions to enable the design of suitable mitigation. To date, a number of approaches have been used. Airborne measurements of both individual and clusters of facilities, along with production data, have been used to scale up to an inventory of $\mathrm{CH}_{4}$ emissions for the US Gulf of Mexico (Gorchov Negron et al., 2020). Shipbased measurements of $\mathrm{CH}_{4}$ and associated source tracers have been made in both the Gulf of Mexico (Yacovitch et al., 2020) and in the North Sea (Riddick et al., 2019). The latter reported fluxes of $\mathrm{CH}_{4}$ from offshore $\mathrm{O} \& \mathrm{G}$ installations in UK waters that were derived from observations made from small boats at $\sim 2 \mathrm{~m}$ above sea level. This approach has advantages in terms of cost, but the authors recognised a number of key uncertainties in their approach associated with assumptions around boundary layer conditions and a lack of 3D information (i.e. Gaussian plume modelling and assump- tions of constant wind speed). Measurements from aircraft can provide this 3D spatial information, enabling better characterisation of both plume morphology and boundary layer dynamics.

Here we report a project that was designed around the use of a small-aircraft with flexible instrument payload suitable for agile deployment. Key objectives were (i) to identify and quantify emissions of $\mathrm{CH}_{4}$ from a suite of offshore gas fields within a limited geographical area and (ii) to develop methodologies that can be applied to gas fields elsewhere to assess emissions at local scales. The project was part of the United Nations Climate \& Clean Air Coalition (UN CCAC) objective to characterise global $\mathrm{CH}_{4}$ emissions from oil and gas infrastructure. Targeted observations of atmospheric $\mathrm{CH}_{4}$ and $\mathrm{C}_{2} \mathrm{H}_{6}$ plus sampling for VOC and $\delta^{13} \mathrm{C}_{\mathrm{CH} 4}$ analysis were made from a Twin Otter aircraft operated by the British Antarctic Survey (BAS). Two campaigns were conducted, one in April 2018 and one in April-May 2019, with a total of 10 flights $(\sim 45 \mathrm{~h})$ over the two campaigns.

The specific aims of the surveys were:

1. $\mathrm{CH}_{4}$ surveying of facilities with a range of expected (from inventories) $\mathrm{CH}_{4}$ emissions

2. resolution of types of emission from installations (such as flaring, venting, combustion and leaks) using carbon-isotopic fingerprinting and analysis of coemitted species (including VOCs).

3. estimation of total $\mathrm{CH}_{4}$ emissions for the target region

4. improvement of flux estimation (and sampling) methodologies for rapid quantification of major gas emissions.

Here, we provide an overview of the measurement platform configuration and sampling strategy during these campaigns, including instrument comparisons for hydrocarbon plume detection, spot sampling strategies for VOCs and $\delta^{13} \mathrm{C}_{\mathrm{CH} 4}$, and flight planning to cope with complex boundary layer meteorology to allow for the estimation of emission fluxes. Analysis methods to determine diagnostic hydrocarbon plume characteristics such as $\mathrm{C}_{2} \mathrm{H}_{6}-\mathrm{CH}_{4}$ ratios and $\delta^{13} \mathrm{C}_{\mathrm{CH} 4}$ source attribution are also discussed. A sister publication will present the estimated facility level emissions in detail and discuss the results in a regional context.

\section{Experimental}

A DHC6 Twin Otter research aircraft, operated by the British Antarctic Survey, was equipped with instrumentation to measure atmospheric boundary layer parameters, including the boundary layer structure and stability, as well as a number of targeted chemical parameters. These included $\mathrm{CH}_{4}, \mathrm{CO}_{2}$, $\mathrm{H}_{2} \mathrm{O}$ and $\mathrm{C}_{2} \mathrm{H}_{6}$ as well as whole-air sampling for subsequent analysis of $\delta^{13} \mathrm{C}_{\mathrm{CH} 4}$ and a suite of VOCs. Here we describe the aircraft capability, aircraft fit and the instruments deployed. 


\subsection{Aircraft capability}

The maximum range of the Twin Otter aircraft during the flight campaigns was approximately $1000 \mathrm{~km}$. Although the aircraft is capable of flying up to $5000 \mathrm{~m}$ altitude, most of the flying was limited to below $2000 \mathrm{~m}$; in regions with no minimum altitude limit, the aircraft could be flown at the practical limit of $15 \mathrm{~m}$ above sea level. The instrument fit included use of a turbulence boom, which limited the speed to a maximum of $140 \mathrm{kn}\left(\sim 70 \mathrm{~ms}^{-1}\right)$; throughout the campaigns, the target aircraft speed for surveying was $60 \mathrm{~ms}^{-1}$. The aircraft was limited to a minimum safe separation distance of $200 \mathrm{~m}$ from any $\mathrm{O} \& \mathrm{G}$ production platforms.

The total weight of the aircraft on take-off is limited to $14000 \mathrm{lb}(6350 \mathrm{~kg})$. Allowing for fuel and crew, this left $2086 \mathrm{~kg}$ for the instrumentation. The total power available on the aircraft is $150 \mathrm{~A}$ at $28 \mathrm{~V}$, and inverters were used to provide $220 \mathrm{~V}$ to those instruments that required it. Altitude and air speed were determined by static and dynamic pressure from the aircraft static ports and heated Pitot tube, logged using Honeywell HPA sensors at $5 \mathrm{~Hz}$. A radar altimeter recorded the flight height at around $10 \mathrm{~Hz}$. An OxTS (Oxford Technical Solutions) inertial measurement system coupled to a Trimble R7 GPS was used to determine the aircraft position and altitude. This system gives all three components of aircraft position, altitude and velocity at a rate of $50 \mathrm{~Hz}$. The chemistry inlets on the Twin Otter are similar to those fitted to the FAAM (Facility for Airborne Atmospheric Measurements) BAe (British Aerospace) 146 large atmospheric research aircraft (e.g. O'Shea et al., 2013) and were fitted with the inlet facing to the rear (Fig. A1). A single line (1/4" Synflex tubing) was taken from the inlet to a high-capacity pump with the instruments branching from this line. The aircraft was fitted out during the week before each of the two flight campaigns, allowing for significant changes to be made between 2018 and 2019 based on instrument performance and data from 2018 (Fig. 1).

\subsection{Boundary layer physics instrumentation}

A fast-response temperature sensor and a nine-hole NOAA BAT "Best Air Turbulence" probe (Garman et al., 2006) were mounted on a boom on the front of the aircraft (see photo, Fig. A2). This instrumental set-up was chosen to reduce flow distortion effects by the aircraft. These fast-response measurements of wind and temperature fluctuations were made with a frequency of $50 \mathrm{~Hz}$. Garman et al. (2006) investigated the uncertainty of the wind measurements by testing a BAT probe in a wind tunnel. They assessed that the precision of the vertical wind measurements due to instrument noise was approximately $\pm 0.03 \mathrm{~ms}^{-1}$. Garman et al. (2008) showed that an additional uncertainty in the wind data occurs when a constant up-wash correction value is used, as proposed by the model of Crawford et al. (1996). We use the Crawford model, which increases the uncertainty in the vertical wind compo- nent, $w$, to approximately $\pm 0.05 \mathrm{~ms}^{-1}$. We assume for the two horizontal wind components, $u$ and $v$, similar high uncertainties due to aircraft movement. A detailed description of the Twin Otter turbulence instrumentation and associated data processing can be found in Weiss et al. (2011).

Ambient air temperature was observed with Goodrich Rosemount Probes, mounted on the nose of the aircraft. A non-de-iced model 102E4AL and a de-iced model 102AU1AG logged the temperature at $0.7 \mathrm{~Hz}$. Atmospheric humidity was measured with a Buck $1011 \mathrm{C}$ cooled-mirror hygrometer. The 1011C Aircraft Hygrometer is a chilledmirror optical dew point system. The manufacturer stated a reading accuracy of $\pm 0.1^{\circ} \mathrm{C}$ in a temperature range of -40 to $+50^{\circ} \mathrm{C}$. Chamber pressure and mirror temperature were recorded at $1 \mathrm{~Hz}$.

\subsection{In situ atmospheric chemistry instrumentation}

A Los Gatos Research (LGR) Ultraportable Greenhouse Gas Analyser (uGGA) was installed to measure $\mathrm{CH}_{4}, \mathrm{CO}_{2}$ and $\mathrm{H}_{2} \mathrm{O}$. The expected manufacturer precision for the $\mathrm{CH}_{4}$ measurement was $<2$ ppb averaged over $5 \mathrm{~s}$ and $<0.6 \mathrm{ppb}$ over $100 \mathrm{~s}$. The response time of the LGR uGGA itself (i.e. the flush time through the measurement cell) was over $10 \mathrm{~s}$. To achieve higher-temporal-frequency data, a fast Picarro G2311-f was installed to provide measurements of $\mathrm{CH}_{4}, \mathrm{CO}_{2}$ and $\mathrm{H}_{2} \mathrm{O}$ at $\sim 10 \mathrm{~Hz}$, with $1 \sigma$ precision of $\sim 1 \mathrm{ppb}$ over $1 \mathrm{~s}$ for $\mathrm{CH}_{4}$. A third greenhouse gas analyser, an LGR Ultraportable $\mathrm{CH}_{4} / \mathrm{C}_{2} \mathrm{H}_{6}$ Analyser (uMEA) was used to measure $\mathrm{CH}_{4}$ and $\mathrm{C}_{2} \mathrm{H}_{6}$. In-house laboratory measurements suggest $\mathrm{C}_{2} \mathrm{H}_{6} 1 \sigma$ precision at $1 \mathrm{~s}$ is $\sim 17 \mathrm{ppb}$ for the LGR uMEA. During the 2019 airborne campaign, atmospheric $\mathrm{C}_{2} \mathrm{H}_{6}$ was also monitored by a tuneable infrared laser direct absorption spectrometer (TILDAS, Aerodyne Research Inc.) (Yacovitch et al., 2014b) with an expected precision of $50 \mathrm{ppt}$ (parts per trillion) for $\mathrm{C}_{2} \mathrm{H}_{6}$ over $10 \mathrm{~s}$. This instrument utilises a continuous wave laser operating in the mid-infrared region (at $\lambda=3.3 \mu \mathrm{m}$ ). A further description of the TILDAS instrument set-up and performance is available in the Appendices along with instrument precisions and response times in Table A1.

\subsection{Calibration of in situ instrumentation}

\subsection{1 $\mathrm{CH}_{4}$ and $\mathrm{CO}_{2}$ calibration}

In situ $\mathrm{CH}_{4}$ and $\mathrm{CO}_{2}$ instruments were calibrated in flight using a manually operated calibration deck, shown in schematic form in Fig. 2. The calibration gases consisted of a suite of WMO-referenced (World Meteorological Organization) standards with a "high", "low" and "target" designation. The high $\mathrm{CH}_{4}$ concentration was $\sim 2600 \mathrm{ppb}$; low was $\sim 1850 \mathrm{ppb}$; and target was $\sim 2000 \mathrm{ppb}$. $\mathrm{CO}_{2}$ concentrations were high at $\sim 468.5 \mathrm{ppm}$, low at $\sim 413.9 \mathrm{ppm}$ and target at $\sim 423.6 \mathrm{ppm}$. The absolute values of the cylinders varied between years as they were re-filled and re-certified to the 


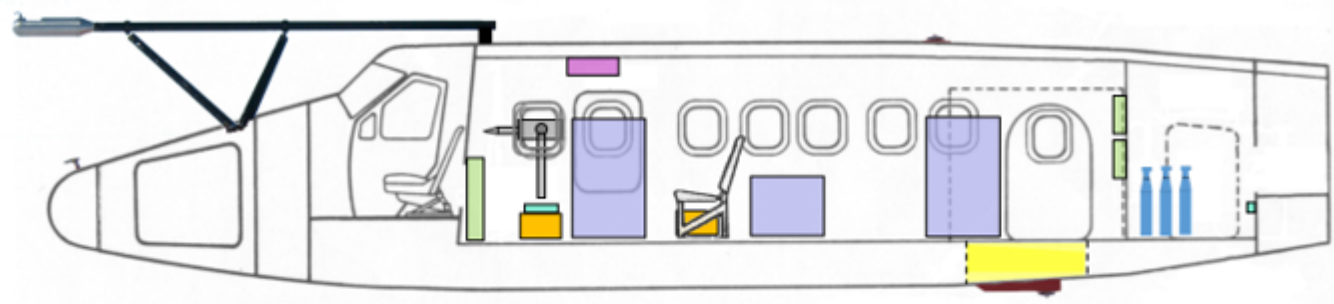

VP-FAZ
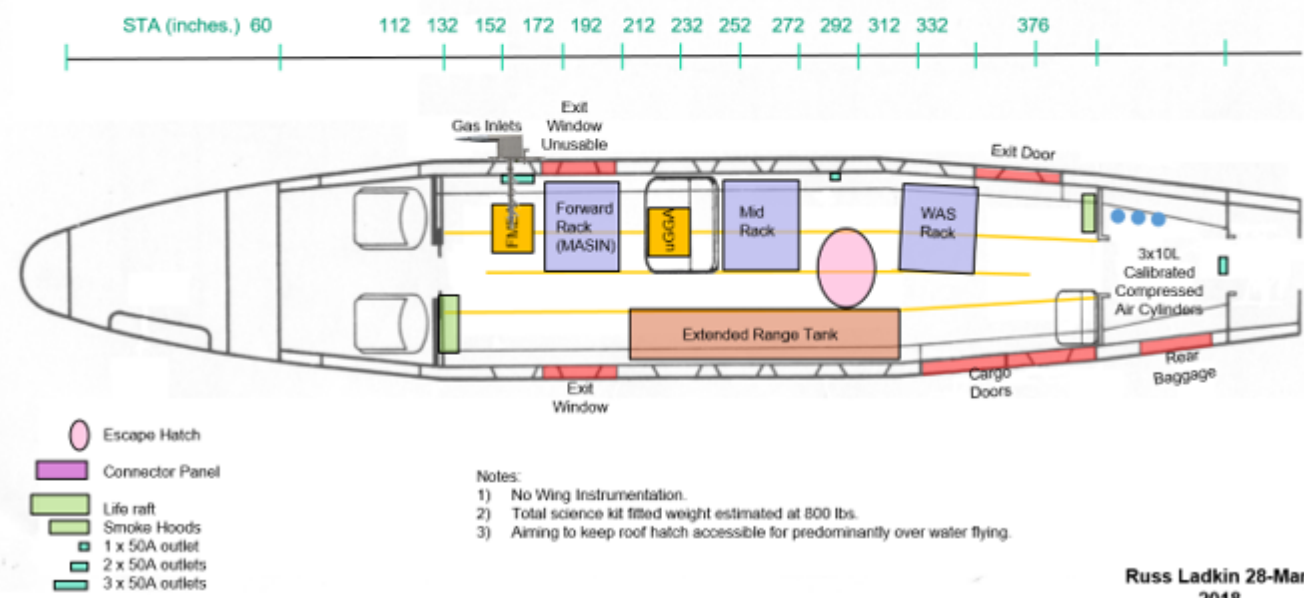

Notes:

1) No Wing instrumentation

testinated at $800 \mathrm{lbs}$

3) Aiming to keep roof hatch acoessble for predominanty over water foing $2 \times 50 A$ outhets

Russ Ladkin 28-Mar2018

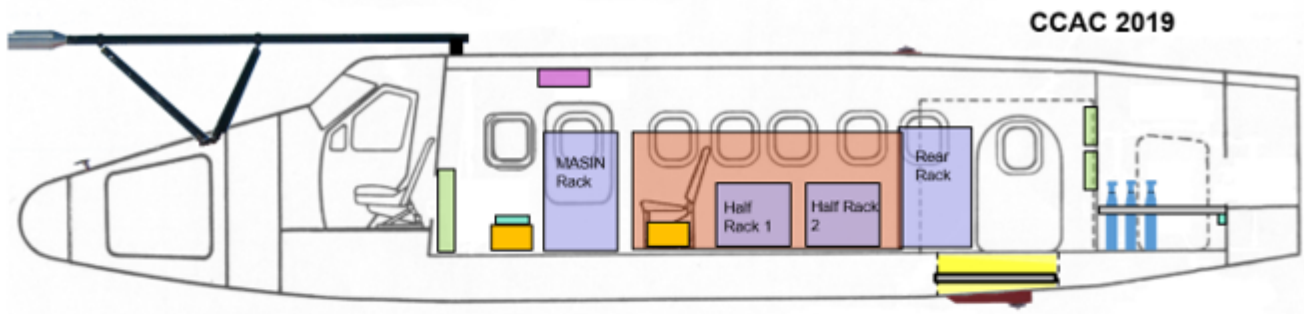

VP-FAZ
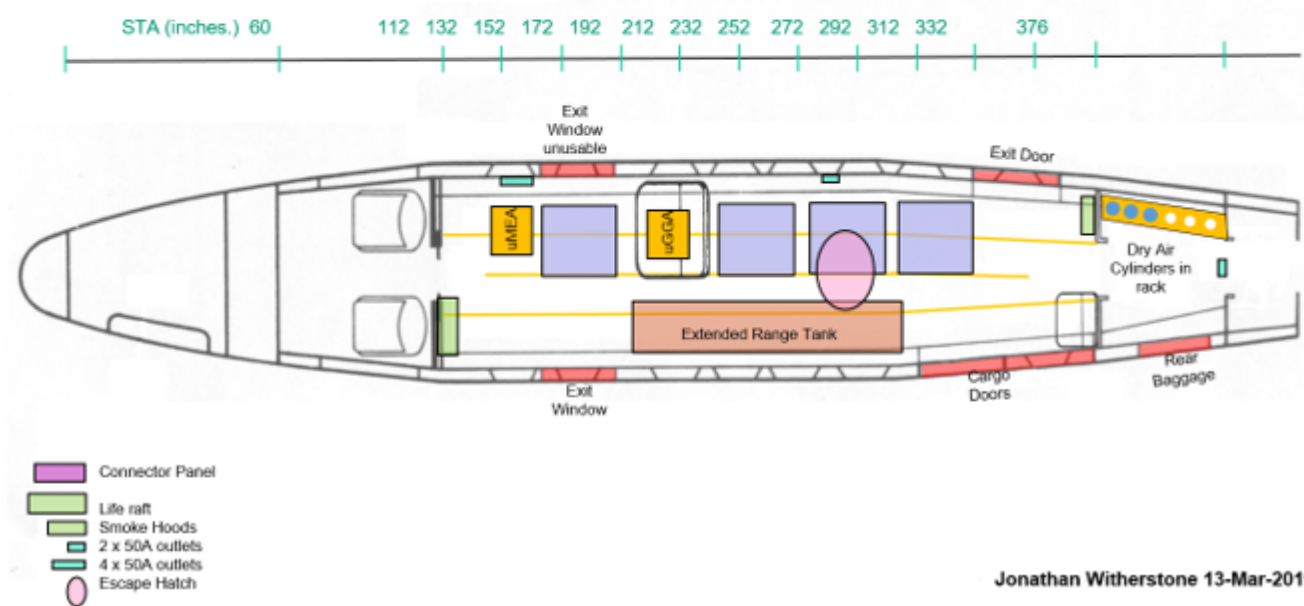

Jonathan Witherstone 13-Mar-2019

Figure 1. Instrument schematics for the Twin Otter aircraft as deployed in 2018 and 2019, detailing changes in layout and instrumentation between the two campaigns. The top panel is the $2018 \mathrm{fit}$, and the lower panel is the 2019 fit. VP-FAZ is the Twin Otter aircraft ID. $(1 \mathrm{in} .=2.54 \mathrm{~cm} ; 1 \mathrm{lb}=0.45 \mathrm{~kg}$.) 
NOAA WMO-CH $4-\mathrm{X} 2004 \mathrm{~A}$ and $\mathrm{WMO}-\mathrm{CO}_{2}-\mathrm{X} 2007$ scales. The calibration deck is designed so that upon the calibration valve opening, the calibration gas flow rate is sufficient to overflow the inlet. A similar approach to in-flight calibration is also applied on the NOAA WP-3D aircraft (Warneke et al., 2016). Full details of the calibration procedure are recorded in the Appendices. $\mathrm{CH}_{4}$ uncertainty $(1 \sigma)$ is calculated from the in-flight target gas measurements as $1.24 \mathrm{ppb}$ for the Picarro G2311-f and $1.77 \mathrm{ppb}$ for the uGGA, giving performance comparable with similar instrumentation on the FAAM aircraft (O'Shea et al., 2014). The excellent agreement between measured and expected values of $\mathrm{CH}_{4}$ for the target cylinder (for the Picarro and uGGA) gives us confidence in being able to operate to high levels of accuracy with a very limited period of instrument fitting and testing. $\mathrm{CO}_{2}$ uncertainty $(1 \sigma)$ at $1 \mathrm{~Hz}$ is calculated as $0.20 \mathrm{ppm}$ for the Picarro G2311-f and $0.35 \mathrm{ppm}$ for the uGGA. More details on the calibration and associated uncertainties are shown in the Appendices.

\subsection{2 $\mathrm{C}_{2} \mathrm{H}_{6}$ calibration}

The calibration cylinders installed on the Twin Otter during both campaigns did not contain measurable amounts of $\mathrm{C}_{2} \mathrm{H}_{6}$, and therefore in-flight calibrations could not be performed. This represents a limitation on the accuracy and traceability of the $\mathrm{C}_{2} \mathrm{H}_{6}$ measurements during these campaigns and will be addressed for future studies using the BAS Twin Otter. The uMEA was calibrated in the laboratory post-campaign for the 2018 campaign and pre- and postcampaign in the laboratory for the 2019 season. The uMEA instrument cavity is not temperature stabilised, resulting in significant measurement drift during the course of operation. Corrections for $\mathrm{C}_{2} \mathrm{H}_{6}$ and $\mathrm{CH}_{4}$ measurement drift as a function of cavity temperature were determined experimentally by analysing two calibration cylinders alternately over the course of several hours as the cavity temperature increased. These corrections were then applied to the uMEA $\mathrm{C}_{2} \mathrm{H}_{6}$ and $\mathrm{CH}_{4}$ measurements obtained from both the 2018 and 2019 flight campaigns.

The TILDAS (deployed in 2019) measures a water line, allowing for measurements to be corrected to dry mole using the TDLWintel software (Nelson et al., 2004) to account for changes in humidity during the flight (as discussed in Pitt et al., 2016). The raw measured data were calibrated preand post-flight using two cylinders of a known concentration, whose mole fractions spanned the measurement range observed during flights for $\mathrm{C}_{2} \mathrm{H}_{6}$. By assuming a linear relationship, the calibrated mole fraction corresponding to each measured TILDAS mole fraction was given by interpolating the scale between the pre- and post-flight calibration reference points. Previous studies have reported the sensitivity of TILDAS systems to aircraft cabin pressure (Gvakharia et al., 2018; Kostinek et al., 2019; Pitt et al., 2016). This sensitivity means that the $\mathrm{C}_{2} \mathrm{H}_{6}$ mole fractions measured during the flight contain a systematic altitude-dependent bias. However, as cabin pressure only affects the spectroscopic baseline, the zero offset of the measurements is affected but not the instrument gain factor. Therefore, as long as each plume measurement is referenced to a measured background at the same altitude, this cabin pressure sensitivity does not significantly impact the calculated $\mathrm{C}_{2} \mathrm{H}_{6}$ mole fraction enhancements. As stated above, future deployments will mitigate this issue by employing in-flight calibration cylinders that are certified for $\mathrm{C}_{2} \mathrm{H}_{6}$. The potential to use a fast, frequent calibration for baseline correction as described by Gvakharia et al. (2018) and Kostinek et al. (2019) will also be investigated, although this has payload implications, as it requires an extra calibration cylinder. Alternatively, the optical bench could be reengineered to sit within a hermetically sealed pressure vessel, as described by Santoni et al. (2014).

\subsection{Spot sampling}

Manually triggered spot sampling provides a cost-effective and relatively simple sample collection method to allow for analyses which cannot be performed mid-flight or require specialist laboratory facilities to gain useful levels of precision. Two discrete air-sampling systems were used during these flights to enable post-flight analysis for VOCs and $\delta^{13} \mathrm{C}_{\mathrm{CH} 4}$.

\subsubsection{Son of Whole Air Sampler (SWAS)}

The Son of Whole Air Sampler (SWAS) is a new, updated version of the parent WAS system fitted to the FAAM BAe 146 large atmospheric research aircraft (e.g. as used by O'Shea et al., 2014), which it is designed to supersede. The system comprises a multitude of inert Silonite-coated (Entech) stainless steel canisters, grouped together modularly in cases with up to 16 canisters per case. Onboard the Twin Otter, two cases can be fitted allowing for up to 32 canisters to be carried per flight. The theory of operation is to capture discrete air samples from outside of the aircraft and compress the sample either into 1.4 or $2 \mathrm{~L}$ canisters at low pressure (40 psi; $275 \mathrm{kPa}$ ) via pneumatically actuated bellows valves (PBVs, Swagelok BNVS4-C). Full details of the operation of SWAS are included in the Appendices. For the 2019 campaign, SWAS was updated with the addition of $2 \mathrm{~L}$ flowthrough canisters, making narrow plumes easier to capture due to reduced sample line lag and fill times.

SWAS canister sampling was manually triggered during the flights according to in situ observations made by fastresponse instrumentation of $\mathrm{CO}_{2}, \mathrm{C}_{2} \mathrm{H}_{6}$ and $\mathrm{CH}_{4}$, with the aim of capturing specific oil and gas plumes. The samples were analysed at the University of York for VOCs postflight using a dual-channel gas chromatograph with flame ionisation detectors (Hopkins et al., 2003). Firstly, $500 \mathrm{~mL}$ aliquots of air are withdrawn from the sample canister and dried using a condensation finger held at $-30^{\circ} \mathrm{C}$; then they 


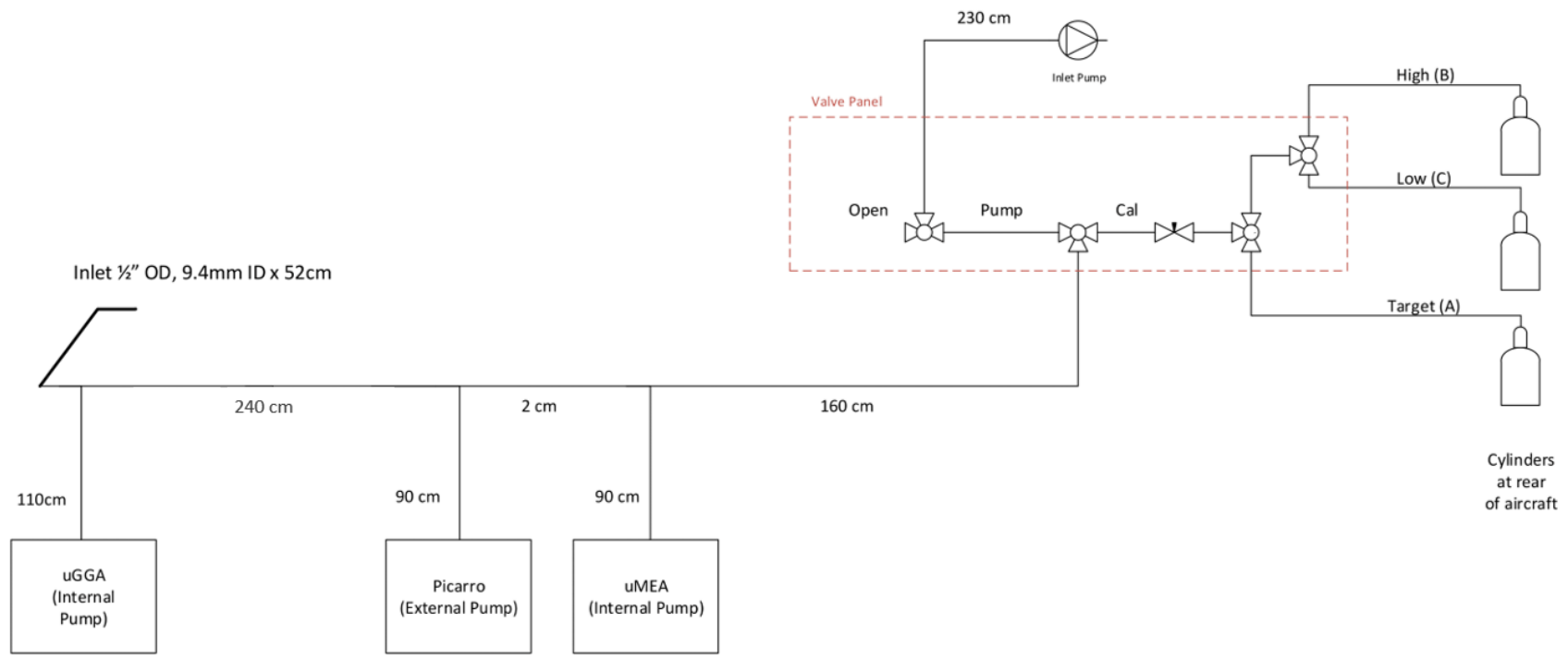

Figure 2. Layout of the plumbing of the calibration system (and inlet system) for the 2018 campaign.

are pre-concentrated onto a multi-bed carbon adsorbent trap consisting of Carboxen 1000 and Carbotrap B (Supelco) and transferred to the gas chromatography (GC) columns $\left(\mathrm{Al}_{2} \mathrm{O}_{3}\right.$, $\mathrm{NaSO}_{4}$ deactivated and open tubular; PLOT - porous layer, open tubular) in a stream of helium. Chromatogram peak identification was made by reference to a calibration gas standard containing known amounts of 30 VOCs ranging from $\mathrm{C} 2$ to $\mathrm{C} 9$. Compounds of interest include $\mathrm{C}_{2} \mathrm{H}_{6}$, propane, butanes, pentanes, benzene and toluene; a full list is shown in Table A2.

\subsubsection{FlexFoil bag sampling}

Spot sampling for $\delta^{13} \mathrm{C}_{\mathrm{CH} 4}$ by collecting whole-air samples into FlexFoil bags (SKC Ltd) has been in use on both the FAAM BAe 146 research aircraft (e.g. Fisher et al., 2017) and during ground-based mobile studies (e.g. Lowry et al., 2020) and provides a relatively cost-effective and rapid methodology for sample collection. The method does have some limitations, however, as the FlexFoil sample bags are only stable for a number of compounds (including $\mathrm{CH}_{4}$ ). Samples captured in both FlexFoil bags and SWAS were measured at Royal Holloway using continuous-flow isotope ratio mass spectrometry (CF-IRMS; Fisher et al., 2006), and each measurement has a $\delta^{13} \mathrm{C}_{\mathrm{CH} 4}$ uncertainty of $\sim 0.05 \%$. Each sample is also measured for $\mathrm{CH}_{4}$ mole fraction using cavity ring-down spectroscopy to allow for direct comparison to in-flight data (Fig. A3). Alternative, continuous in-flight $\delta^{13} \mathrm{C}_{\mathrm{CH} 4}$ instrumentation currently cannot replicate the precision of laboratory sampling, and the few seconds of enhanced $\mathrm{CH}_{4}$ that would be encountered during flight is not sufficient for averaging of continuous $\delta^{13} \mathrm{C}_{\mathrm{CH} 4}$ data to gain a meaningful source $\delta^{13} \mathrm{C}_{\mathrm{CH} 4}$ signature (e.g. Rella et al., 2015).

\section{Overall approach to flight planning}

The majority of flights were conducted during good operating conditions, i.e. daytime, no precipitation, clear or broken cloud, winds $<10 \mathrm{~ms}^{-1}$, and visibility, to allow for flying at a minimum safe altitude around the task area. Two approaches were trialled to assess $\mathrm{CH}_{4}$ emissions from offshore gas installations: (i) regional survey and (ii) specific plume sampling. The flight modes are demonstrated in Fig. 3, with the dark-grey pattern showing a flight plan for regional measurements and the orange and white patterns demonstrating specific plume sampling flight patterns. Flight plans to sample specific installations were designed to capture a full range of expected emissions using the UK National Atmospheric Emissions Inventory (NAEI) as a guide.

Regional survey intentions were twofold: firstly, to offer an identification process for emitters of interest that could specifically be targeted for plume sampling modes and, secondly, to build a picture of aggregate bulk emissions for multiple upwind platforms. This method has been successfully employed during a Gulf of Mexico airborne study (Gorchov Negron et al., 2020). However, in the work presented here, regional surveys were poor for identifying plumes (being too far downwind of platforms or not intercepting thin filament layers containing $\mathrm{CH}_{4}$ enhancements), and attempts to aggregate bulk emissions were hindered by the often encountered complex boundary layer structure over the area, which controlled dispersion of $\mathrm{CH}_{4}$ emissions from rigs. From the re- 


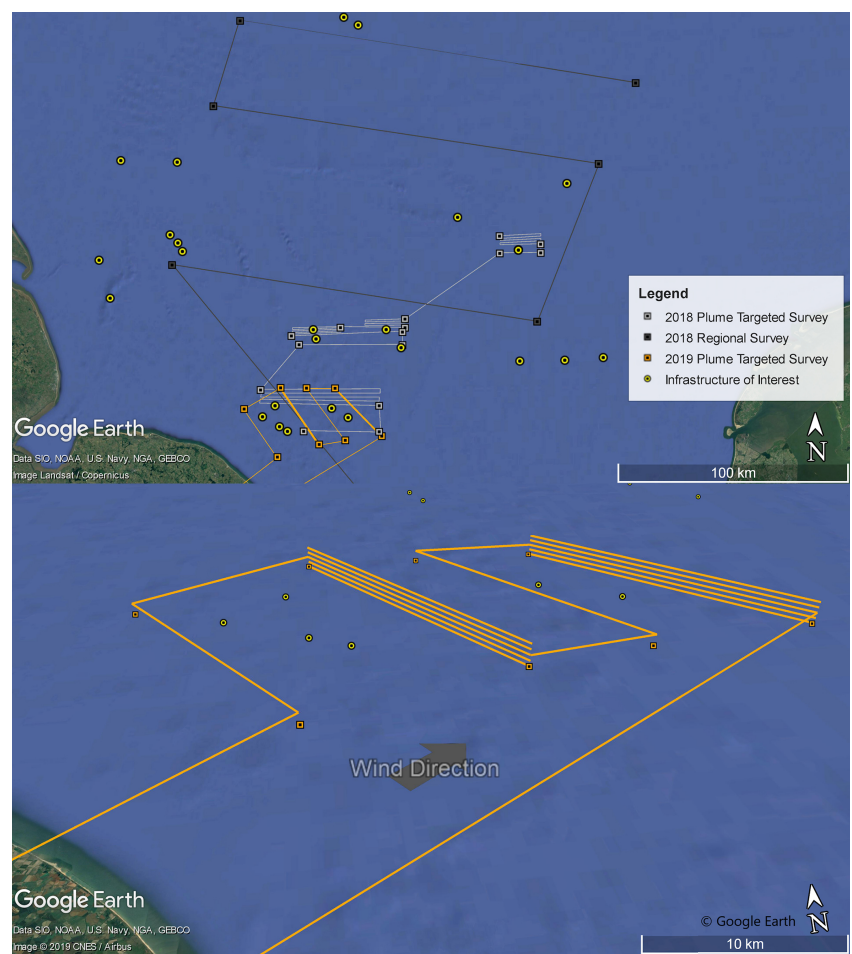

Figure 3. The top panel shows flight patterns of the regional and plume capture styles of flight deployed between 2018 and 2019, alongside infrastructure of interest (such as drilling rigs, gas distribution platforms or production platforms). The bottom panel shows a 2019 plume sampling survey of idealised stacked transects in the 2D plane downwind of infrastructure of interest. (C) Google Earth 2019 for background imaging.

gional flight data derived in 2018 and considering the work in other offshore studies in this area (e.g. Cain et al., 2017), the regional flight mode was determined to be of limited scientific value in the context of this project, and this flight pattern was not used during the 2019 campaign.

Plume sampling flights were conducted in both 2018 and 2019. These flights involved the use of a box pattern to create both upwind and downwind transects on either side of the infrastructure of interest. Upwind transects provided an understanding of other methanogenic sources (such as other installations, ships or long range transport of air masses from onshore sources) that could interfere with observed $\mathrm{CH}_{4}$ plumes downwind and were conducted to be confident that plumes were solely originating from the targeted infrastructure. Vertically stacked downwind transects at a distance of 1 to $10 \mathrm{~km}$ away from emission sources were conducted to better capture the vertical extent of the plume in a $2 \mathrm{D}$ Lagrangian plane for $\mathrm{CH}_{4}$ flux quantification using mass balance analysis (e.g. O'Shea et al., 2014). The vertically stacked transects in profile, as planned from the 2019 field deployment, are demonstrated in Fig. 3. The separation between vertically stacked transects was usually $60 \mathrm{~m}$ with a minimum absolute height of $45 \mathrm{~m}$ above sea surface up to approximately $260 \mathrm{~m}$ to capture the entire extent of a downwind plume. Plume dispersion was dependent on meteorology and emission type (venting, fugitive or combustive emissions), and as such, maximal plume heights varied between individual pieces of infrastructure. Upwind transects were flown at a median height between the minimum and maximum stacked runs.

\section{Assessing and addressing issues encountered during flights}

A number of issues were encountered during the flights that influenced the measurements made. An initial presentation of these issues is given here, with recommendations for improvements given in Sect. 6 below.

\subsection{Complex marine boundary layers}

Boundary layer structure proved to be a important influence on observed $\mathrm{CH}_{4}$ mixing ratios. Figure 4 shows the measured profiles of $\mathrm{CH}_{4}$ (left-hand panel) and potential temperature (right-hand panel) during an offshore flight in April 2018 along with the corresponding synoptic chart. Potential temperature was calculated as described by Stull (1988). The potential temperature profile demonstrates that the boundary layer structure on this day (and many other days) was partly stable stratified, showing mostly an increase in potential temperature with height, and the boundary layer showed complex layering. The prevailing meteorological situation at that time, illustrated by the synoptic chart in Fig. 4, was of a persistent anticyclonic ridge, stretching from the south-west over the British Isles and western Europe, with associated low wind speeds and poorly defined airflow over the southern North Sea sector. The observed layering was partly also caused by residual boundary layers from previous days and nights which had not dispersed. The structure of the boundary layer in Fig. 4 clearly had an important influence on the vertical profile of $\mathrm{CH}_{4}$, which varied and shows a complex profile with height. Due to the complexity of the boundary layer structure, it was concluded that it would be inappropriate to use a particle dispersion model such as the Numerical Atmospheric-dispersion Modelling Environment (NAME) (Jones et al., 2007) to derive a bulk regional emission estimate. The impact of the residual layers of $\mathrm{CH}_{4}$ enhancement make in-flight decisions very challenging for two main reasons: (i) it is difficult to determine which enhancements are from installations and require further investigation, especially if flying at some distance downwind from a potential source or on a regional survey pattern, and (ii) emissions being actively released can become trapped in vertically thin filaments, which can be easily missed when flying stacked legs, depending on flight altitude. In contrast, on days with a well-mixed boundary layer the $\mathrm{CH}_{4}$ profile stays relatively constant with height and shows an increase only near a $\mathrm{CH}_{4}$ 
source. Figure 5 shows an example of $\mathrm{CH}_{4}$ and potential temperature profiles, in a well-mixed boundary layer during a flight in May 2019; the synoptic situation on that day was consistent with a slow-moving cyclonic south-easterly airflow. It can clearly be seen how the potential temperature and $\mathrm{CH}_{4}$ profiles stay almost constant with height and only show structure when intercepting a $\mathrm{CH}_{4}$ emission at 300 to $350 \mathrm{~m}$ altitude. The potential temperature profile indicates neutral stratification of the boundary layer.

\subsection{Instrument response times}

The role of the continuous in-flight measurements is to provide the backbone of the dataset and ensure that, at a bare minimum, the flights are able to identify areas of $\mathrm{CH}_{4}$ enhancement and inform on the likely sources of the $\mathrm{CH}_{4}$ enhancement, hence the decision to run redundancy measurements of $\mathrm{CH}_{4}$ utilising an LGR uGGA. Figure 6 shows typical instrument responses to a $\mathrm{CH}_{4}$ plume, and it is clear that the cell turnover time of the uGGA is not sufficient to capture the fine detail of the plume. Whilst the uGGA and uMEA are capable of determining the whole infrastructure mass balance and average infrastructure ethane-methane ratios, the refined understanding of the true plume is lost in these slower response instruments. This is important, as the combined Picarro G2311-f and TILDAS data can detect several sources from the same installation (Fig. 6) because of their rapid measurement cell turnover. This information can be used to infer either cold venting $\left(\mathrm{CH}_{4}\right.$ and $\left.\mathrm{C}_{2} \mathrm{H}_{6}\right)$ or combustion from flares or generators $\left(\mathrm{CO}_{2}, \mathrm{CH}_{4}\right.$ and $\left.\mathrm{C}_{2} \mathrm{H}_{6}\right)$, which could then be used to determine $\mathrm{CH}_{4}$ emission factors from identified flares (Gvakharia et al., 2017).

There are a number of other implications that arise from slow measurement response. For example, in-flight spot sampling requires guidance from fast-response instruments that can indicate the optimum timing to collect samples that span the plume and thereby capture the representative chemical nature of the plume. Further, in-flight calibrations must be matched to the slowest-response instrument to ensure stabilisation of the measurement of calibration gases across all instruments. Although useful from a cross-checking purpose, use of slower-response instruments can introduce additional, unwanted loss of measurement time and excessive use of calibration gases, and the benefits of instrument redundancy should be carefully considered.

\subsection{Spot sampling improvements between the 2018 and 2019 campaigns}

In-flight spot sample collection was carried out during both the 2018 and 2019 campaigns. Such sampling is challenging and requires fast-response instruments to be viewable to the operator to give the best chance of collecting samples at appropriate points across the plumes. For 2019, a number of simple adaptations were introduced that significantly increased the success of capturing plumes (Fig. A3). The improvements included modified flight planning, with an increased number of passes through discovered plumes. This approach resulted in increased fuel consumption per plume but contributed to the higher success rate of plume capture. The comprehensive update to the SWAS system, which included continuous sample throughflow allowed for more precise spot sampling to be achieved.

\section{Creation of data products}

\subsection{Methane fluxes}

A methane flux can be calculated from the $\mathrm{CH}_{4}$ mixing ratio data using mass balance techniques (e.g. O'Shea et al., 2014; Pitt et al., 2019) in which a vertical 2D plane is defined at a fixed distance downwind of the infrastructure of interest, and sampling is conducted across the stacked transects at this distance if a plume is identified in the downwind plane. Fluxes were derived using Eq. (1):

Flux $=\left(X_{\text {plume }}-X_{\text {background }}\right) \times n_{\text {air }} \times V \times \Delta x \times \Delta z$,

where Flux is the bulk net flux passing through the $x-z$ plane per unit time, $n_{\text {air }}$ is the molar density of air $\left(\mathrm{mol} \mathrm{m}^{-3}\right)$, $X_{\text {plume }}$ is the average $\mathrm{CH}_{4}$ mole fraction measured within the plume and $X_{\text {background }}$ is the $\mathrm{CH}_{4}$ mole fraction of the background. $V$ is the wind component perpendicular to the flight track; $\Delta x$ is the plume width perpendicular to the upwinddownwind direction; and $\Delta z$ relates to the vertical extent of the plume.

The $\mathrm{CH}_{4}$ and $\mathrm{CO}_{2}$ measurements from the $10 \mathrm{~Hz}$ response instruments were used to provide the highest accuracy in the (i) lateral plume width and (ii) number of unique plumes identified from each individual platform. Slower-response instruments would allow for flux calculations but would not be able to identify individual plumes from the same platform. This could be useful to distinguish, for example, multiple plumes from different emission processes that are spatially distinct within the same platform (e.g. a fugitive source versus a flare). A background mixing ratio was selected to best represent the conditions observed during the flight at the specific time of survey. An average of $30 \mathrm{~s}$ of data from either side of the plume on each run were used if this was deemed appropriate with a clean upwind sampling leg. When the upwind sampling was contaminated, more caution should be taken when selecting an appropriate background so that the background value is not distorted by extraneous far-field sources.

For the flux analysis, a flux across each individual stacked horizontal run downwind of a plume was calculated before scaling in the vertical component. The flux was then integrated across potential minimum and maximum plume depths. Figure 7 (upper panel) represents a reduced vertical resolution of the plume where transects at intermediate alti- 

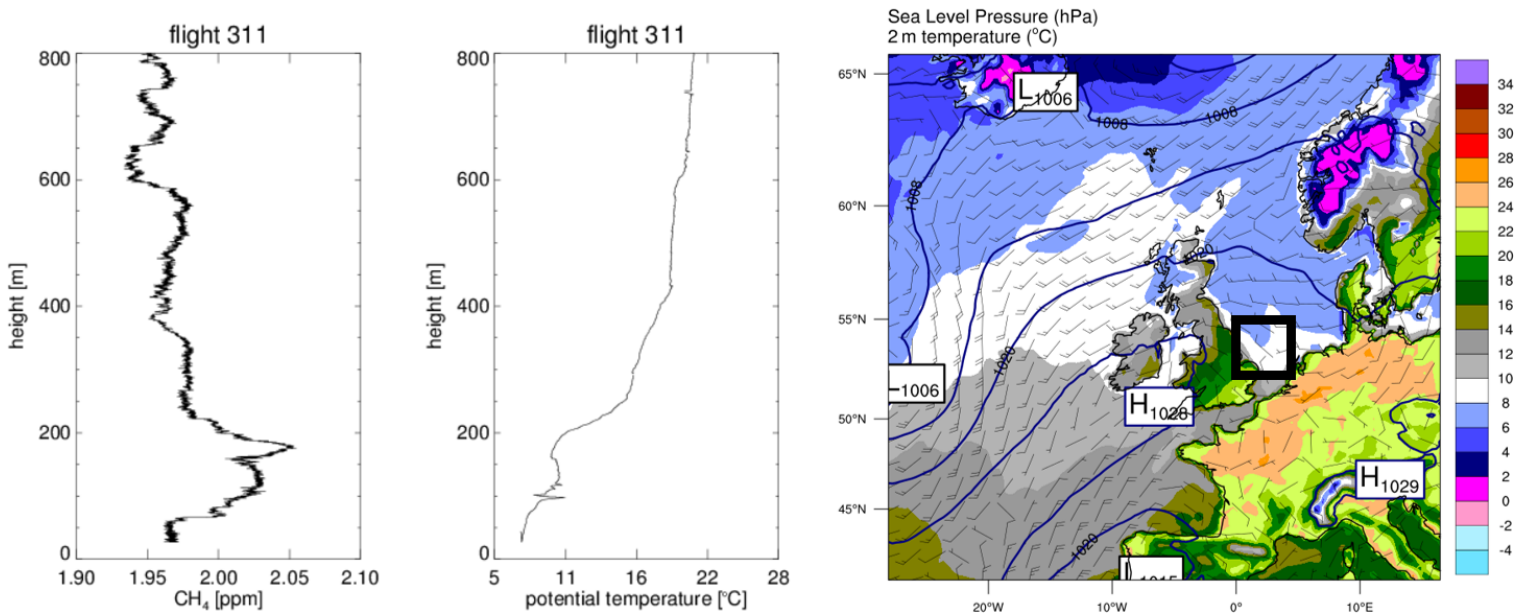

Figure 4. Example of $\mathrm{CH}_{4}$ and potential-temperature profiles showing the large amount of structure arising from residual boundary layers. The increase of the potential temperature with height shows stable stratification of the boundary layer. The synoptic chart over the eastern North Atlantic and north-western Europe shows contoured sea level pressure $(\mathrm{hPa}), 2 \mathrm{~m}$ temperature $\left({ }^{\circ} \mathrm{C}\right.$, right-hand side colour scale) and wind for 20 April 2018 12:00 UT and reveals relatively low wind speeds and poorly defined airflow over the southern North Sea sector, allowing for the build-up of residual boundary layers. Synoptic chart image produced by the UK National Centre for Atmospheric Science (NCAS) using Weather Research and Forecasting model WFR-ARW (Advanced Research WRF) version 3.7.1, with a $20 \mathrm{~km}$ grid spacing and 51 vertical levels initialised using the NOAA Global Forecast System. NCAS (National Centre for Atmospheric Science) Weather Research Catalogue (https://sci.ncas.ac.uk/nwr/pages/home, last access: 6 November 2020). The black rectangle approximates the survey region.
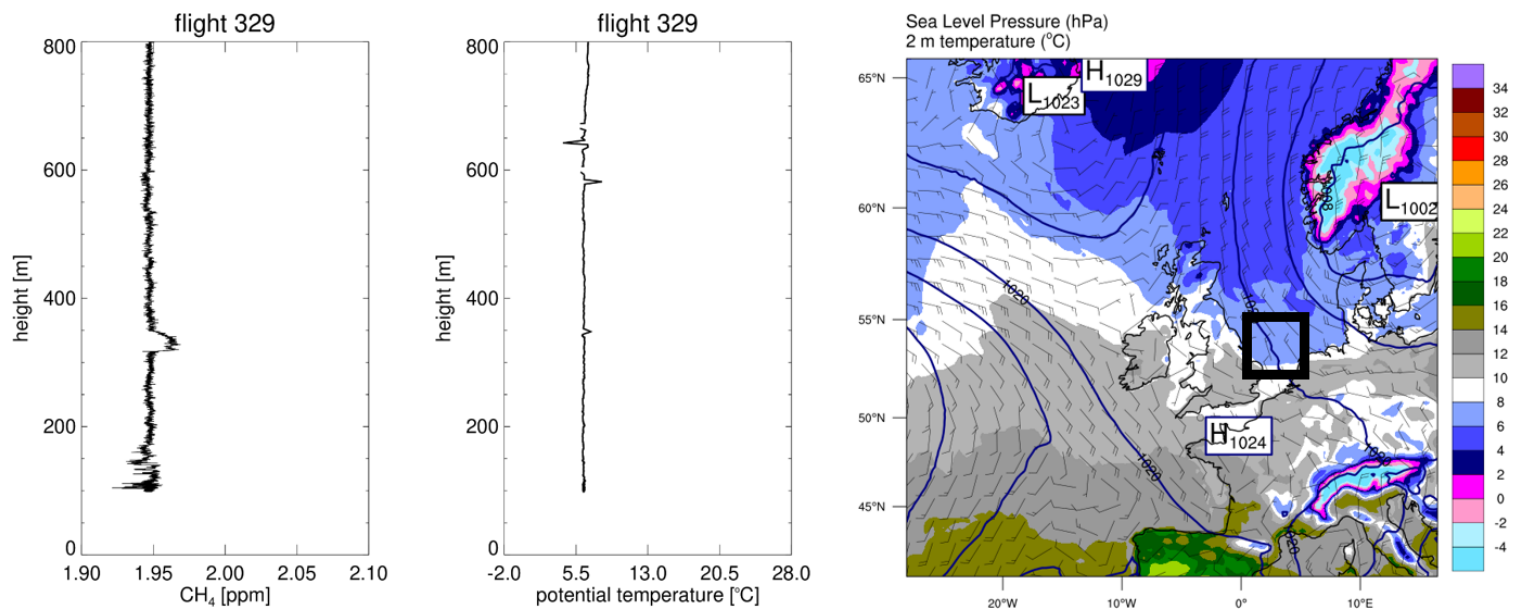

Figure 5. Example of $\mathrm{CH}_{4}$ and potential-temperature profiles in a well-mixed boundary layer under neutral conditions. The potential temperature and $\mathrm{CH}_{4}$ profiles stay relatively constant and $\mathrm{CH}_{4}$ shows only an increase in the surface layer and when intercepting an enhancement at 300 to $350 \mathrm{~m}$ height. The synoptic chart for 6 May 2019 12:00 UT shows a cyclonic south-easterly airflow over the southern North Sea sector originating from the Benelux region. The black rectangle approximates the survey region over open water.

tudes through the plume were not conducted. In this case, the minimal plume depth is the narrow span captured by observation in the $45.9-51.9 \mathrm{~m}$ altitude window. The maximal plume depth is taken as the height difference between the highest and lowest transects without $\mathrm{CH}_{4}$ enhancements, which are above and below the plume, respectively; this value has to be used as the maximum due to incomplete sampling of the void area seen in the upper panel of Fig. 7. In cases where the base and top of the plume were not sampled (e.g. during 2018 sampling), the lower limit was selected as the sea surface, and the upper limit of the plume was selected as the atmospheric marine boundary layer. The greatest uncertainty in bulk flux arises when the vertical extent of the plume is not fully captured. For the 2019 campaign, the flux uncertainty related to plume depth was reduced by a factor of 10 compared to the 2018 campaign (as seen in Table 1) by completing a rigorous set of stacked transects at multiple heights throughout the plume. The fluxes presented here serve to demonstrate the approach and the impact of sampling strategy and meteorological conditions on the calculation. Flux estimates for 


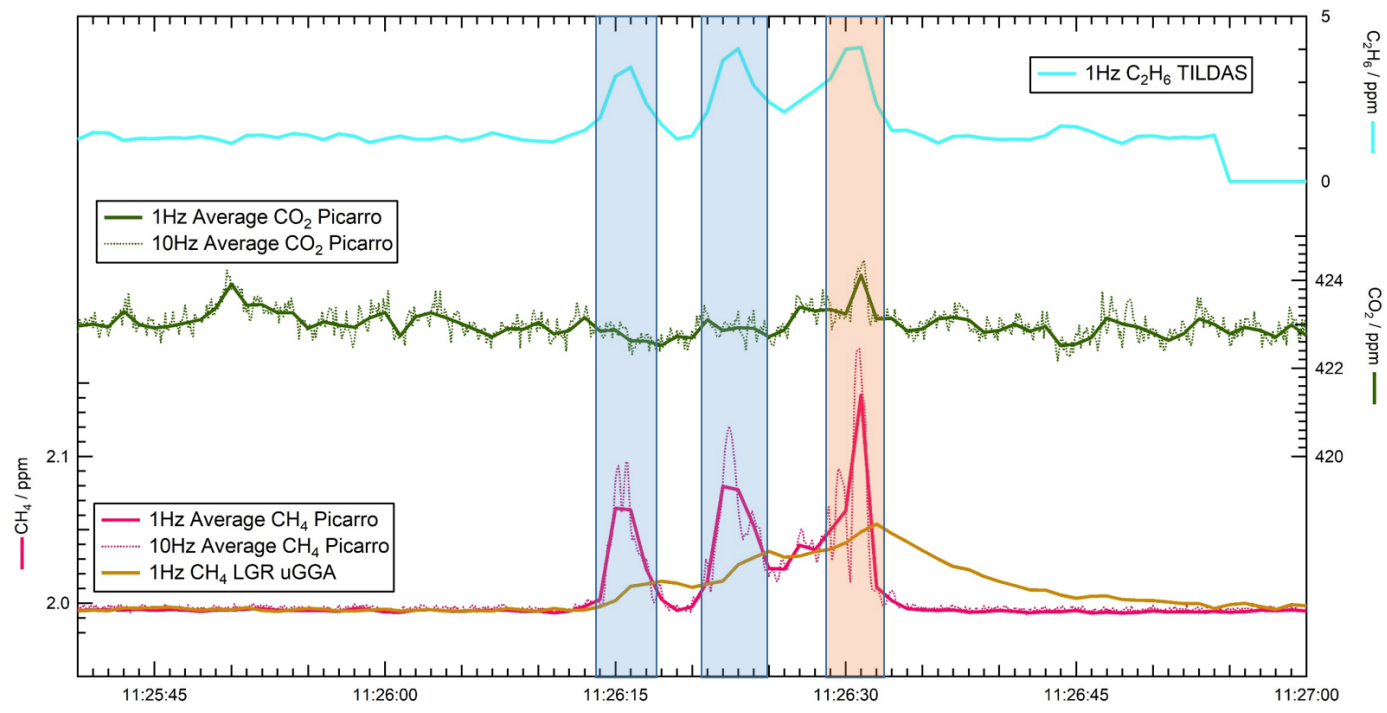

Figure 6. A cross section of $\mathrm{CH}_{4}, \mathrm{CO}_{2}$ and $\mathrm{C}_{2} \mathrm{H}_{6}$ measurement response during one plume sample as recorded by Picarro $\mathrm{G} 2311-\mathrm{f}$ in pink and green $(10 \mathrm{~Hz}$ as dashed lines and downsampled to $1 \mathrm{~Hz}$ as solid lines), TILDAS $1 \mathrm{~Hz}$ in cyan and Los Gatos uGGA $1 \mathrm{~Hz}$ in brown. The difference between the uGGA and Picarro at $1 \mathrm{~Hz}$ arises from the slower uGGA response time is due to the slower cell turnover. The blue-shaded area shows enhancement in $\mathrm{C}_{2} \mathrm{H}_{6}$ and $\mathrm{CH}_{4}$, indicating cold venting; the orange-shaded area shows enhancement in $\mathrm{C}_{2} \mathrm{H}_{6}$, $\mathrm{CH}_{4}$ and a small amount of $\mathrm{CO}_{2}$ potentially indicating a co-located combustion source.
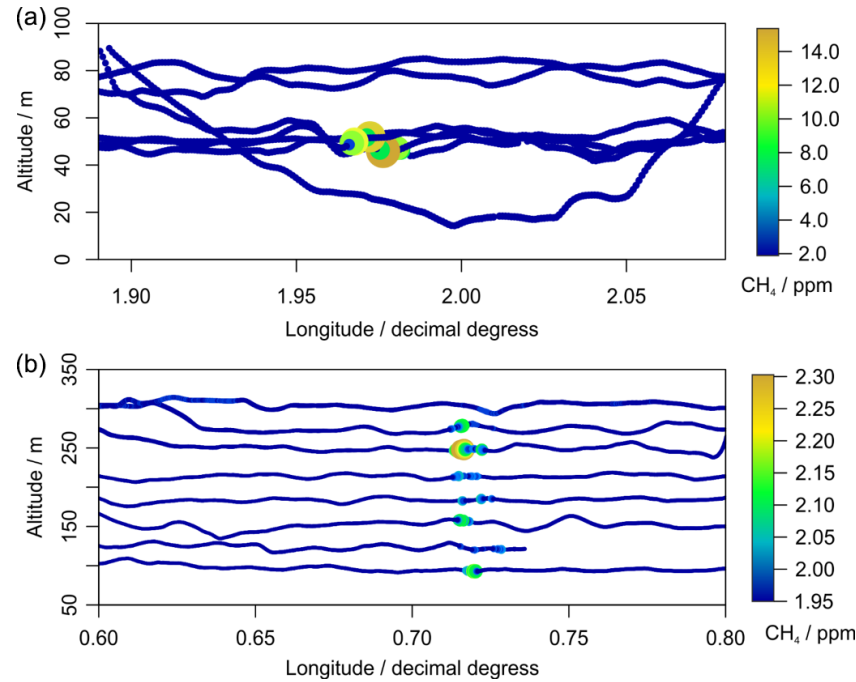

Figure 7. Plumes measured from separate installations to demonstrate the differences in strategies between 2018 and 2019. (a) Plume sampled downwind with poorer vertical spatial resolution in the 2D plane during the 2018 portion of the campaign. $\mathrm{CH}_{4}$ measured values are much higher due to platform activities during the survey time. (b) Plume sampled downwind in 2019 with intermediate transects enabling higher vertical spatial resolution. Note that the colour scale across each plot signifies different measured $\mathrm{CH}_{4}$; the scales on the upper and lower plots are different.

all sampled platforms will be presented in a future study, including a full treatment of component uncertainties.
Table 1. A comparison of flux lower and upper bounds for two individual example plumes across each year of survey as scaled by the vertical resolution available. The plumes themselves are not comparable, but the method changes demonstrate the increased certainty in the final results.

\begin{tabular}{lrr}
\hline $\begin{array}{l}\text { Survey } \\
\text { year }\end{array}$ & $\begin{array}{r}\mathrm{CH}_{4} \text { flux lower } \\
\text { bound }\left(\mathrm{kT} \mathrm{yr}^{-1}\right)\end{array}$ & $\begin{array}{r}\mathrm{CH}_{4} \text { flux upper } \\
\text { bound }\left(\mathrm{kT} \mathrm{yr}^{-1}\right)\end{array}$ \\
\hline 2018 & 1.83 & 17.9 \\
2019 & 0.67 & 1.04 \\
\hline
\end{tabular}

\subsection{Ethane-methane ratios $(\mathrm{C} 2: \mathrm{C} 1)$ as a source tracer}

It has already been well established that continuous $\mathrm{C}_{2} \mathrm{H}_{6}$ measurements can be an excellent diagnostic tool for ascribing enhancements of co-located $\mathrm{CH}_{4}$ and $\mathrm{C}_{2} \mathrm{H}_{6}$ to natural gas emissions in both urban areas (e.g. Plant et al., 2019), semi-rural areas (e.g. Lowry et al., 2020) and during largescale evaluations of oil and gas fields from aerial studies in the USA (e.g. Peischl et al., 2018), Canada (Johnson et al., 2017) and the Netherlands (Yacovitch et al., 2018). During this work, two methods were used to establish $\mathrm{C}_{2} \mathrm{H}_{6}-\mathrm{CH}_{4}$ ratios (hereafter, described as $\mathrm{C} 2: \mathrm{C} 1$ ). In 2018 the LGR uMEA was used to measure $\mathrm{C}_{2} \mathrm{H}_{6}-\mathrm{CH}_{4}$ ratios. The benefits of such instrumentation are in its simplicity of operation and that few considerations are required for corrections or variable lags, as both species are measured at the same rate and within the same optical cavity. $\mathrm{C} 2$ : $\mathrm{C} 1$ can therefore be readily determined as the gradient of a linear regression be- 
tween the $\mathrm{C}_{2} \mathrm{H}_{6}$ and $\mathrm{CH}_{4}$ measurements. However, the low sensitivity to $\mathrm{C}_{2} \mathrm{H}_{6}$ (standard deviation of $>10 \mathrm{ppb}$ in $\mathrm{C}_{2} \mathrm{H}_{6}$ over $10 \mathrm{~s}$ of background flying) only allowed emissions from two platforms to be characterised for $\mathrm{C} 2$ : $\mathrm{C} 1$ ratios during the whole of the 2018 campaign and none during 2019 using the LGR uMEA method.

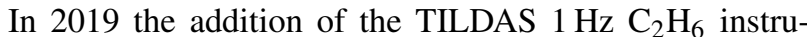
ment allowed for better precision of $\mathrm{C}_{2} \mathrm{H}_{6}(<1 \mathrm{ppb})$ with a faster flush time in the measurement cell. The $\mathrm{C}_{2} \mathrm{H}_{6}$ data are time-matched with the $1 \mathrm{~Hz}$ Picarro $\mathrm{CH}_{4}$ dataset to allow $\mathrm{C} 2$ : $\mathrm{C} 1$ derivation. As the instruments do not have the exact same flow rate and different cell residence times, the $\mathrm{C} 2$ : $\mathrm{C} 1$ ratios were determined using the integral of each $\mathrm{CH}_{4}$ and $\mathrm{C}_{2} \mathrm{H}_{6}$ enhancement using Gaussian peak fitting. A comparison between the 2018 flight, 2019 flight and published data derived from the same geographical area is shown in Table 2. Although both instruments have been operated for this work without in-flight calibration or engineering solutions to address cabin-pressure-sensitivity issues (Gvakharia et al., 2018) due to weight and time constraints, the agreement between years and with published expected values is highly reassuring. The added value in high-precision $\mathrm{C} 2$ : $\mathrm{C} 1$ demonstrates that $\mathrm{C}_{2} \mathrm{H}_{6}$ is not just a tracer for matching emissions to natural gas; it can give information as to proportions of emissions from mixed sources (as previously used by Peischl et al., 2018) or can be used to identify a likely emission point in a process chain depending upon enrichment or depletion of $\mathrm{C}_{2} \mathrm{H}_{6}$ relative to $\mathrm{CH}_{4}$. The inclusion of a continuous instrument with a level below parts per billion (sub-ppb) of detection for $\mathrm{C}_{2} \mathrm{H}_{6}$ is considered vital for future work with thermogenic sources of $\mathrm{CH}_{4}$ to allow for more precise source attribution of emissions where no spot sampling has occurred.

\section{$5.3 \delta^{13} \mathrm{C}_{\mathrm{CH} 4}$ for $\mathrm{CH}_{4}$ source attribution}

The principal method of $\delta^{13} \mathrm{C}_{\mathrm{CH} 4}$ source characterisation utilises the principles outlined by Keeling (1961) and Pataki et al. (2003) and has been well utilised since to create $\delta^{13} \mathrm{C}_{\mathrm{CH} 4}$ databases for a plethora of known $\mathrm{CH}_{4}$ sources (e.g. Sherwood et al., 2017). In order for a Keeling plot to give useful results to determine a $\delta^{13} \mathrm{C}_{\mathrm{CH} 4}$ source signature of a $\mathrm{CH}_{4}$ emission, the emission must have been successfully captured multiple times and with a range of $\mathrm{CH}_{4}$ mixing ratios (which could be achieved by passes at different distances or heights downwind of a point source). This sampling process takes time (especially on an aircraft), where the emission plume is only intercepted once per transect and time in the plume is limited so that only one spot sample can be taken whilst "in-plume". Beyond the time limitations, sampling of a range of $\mathrm{CH}_{4}$ mixing ratios from emissions and appropriate background samples is not straightforward. Background sampling must capture the air into which emissions are released, but during flights the meteorological conditions often resulted in significant variation of $\mathrm{CH}_{4}$ mixing ratios and $\delta^{13} \mathrm{C}_{\mathrm{CH} 4}$ with altitude, in addition to horizontal variations.
Where repeat transects were conducted at different altitudes, this made selection of appropriate background samples for Keeling plots challenging, since the background $\mathrm{CH}_{4}$ mixing ratio and $\delta^{13} \mathrm{C}$ varied over the different altitudes. This becomes particularly detrimental to Keeling plot validity where the range in sampled emission mixing ratios is small, since uncertainty in the background samples then becomes more important.

In Fig. 8, a sensitivity analysis is presented from one of the flights investigating the effect of reducing the number of samples on the uncertainty in the $\delta^{13} \mathrm{C}_{\mathrm{CH} 4}$ source signature determined for a plume. In this case nine samples were collected, but this took place over eight downwind transects and one upwind transect of a cluster of installations, which is not feasible to repeat for sampling large numbers of installations. As shown in Fig. 8, the uncertainty in the $\delta^{13} \mathrm{C}_{\mathrm{CH} 4}$ source signatures increases only slightly with a reduction in number of sampling points, with the exception of one $n=3$ run where the source signature is poorly defined. A minimum of three data points can therefore be sufficient for classifying a source of $\mathrm{CH}_{4}$ emissions (such as thermogenic, microbial or pyrogenic sources), providing that the background and point samples are captured with a large enough range of $\mathrm{CH}_{4}$ concentration and providing that there is no mixing of sources. This will typically require collection of more than three samples, given some may miss the targeted plumes or potentially be lost during storage or processing as aforementioned. Although a two-point Keeling plot is technically possible, it is impossible to gauge the quality of the regression to be sure that only a single source has been captured.

\section{Conclusions}

Given the restrictions and time constraints on the science flights, important lessons for offshore oil and gas airborne measurement campaigns have been learned for rapid instrument re-fitting and agile deployment of a small aircraft for future campaigns. A key finding from this study is that offshore meteorological conditions define the ability of the flights to produce valuable data and suitable meteorology with a wellmixed (neutral) boundary layer is critical to deriving a regional emission estimate through regional modelling. Flying in conditions with multiple residual boundary layers makes interpretation difficult and pin-pointing emissions especially challenging, as emission plumes can easily be missed when they are trapped in thin filaments, increasing the uncertainties of measurement-based emission flux calculations. Although not possible for this work given aircraft scheduling, it is recommended that offshore observations are scheduled with a long window of opportunity to ensure optimal flying conditions. Predictions of the likelihood of a residual boundary layer over a coastal area could be achieved through highspatial-resolution forecast models such as the UK Met Office forecast model (Milan et al., 2020). Information on the 
Table 2. Reported data for $\mathrm{C} 2$ : C1 for a single installation surveyed during both the 2018 and 2019 surveys. Well data from UK oil and gas authority report are available at https://dataogauthority.blob.core.windows.net/external/DataReleases/ShellExxonMobil/GeochemSNS. zip (last access: 7 January 2020) alongside measured $\mathrm{C} 2: \mathrm{C} 1$ for $\mathrm{CH}_{4}$ enhancements measured during flights in the same geographic area.

\begin{tabular}{lllrr}
\hline & Instrument(s) & Method & C2: C1 & Uncertainty \\
\hline 2018 flight & Los Gatos ultraportable $\mathrm{CH}_{4} / \mathrm{C}_{2} \mathrm{H}_{6}$ & Linear regression & 0.029 & \pm 0.014 \\
2019 flight & TILDAS C $2 \mathrm{H}_{6}$ and Picarro $\mathrm{G} 2311-{\mathrm{f} \mathrm{CH}_{4}}_{4}$ & Plume area integration & 0.029 & \pm 0.003 \\
Published well data & & & 0.031 & \pm 0.009 \\
\hline
\end{tabular}
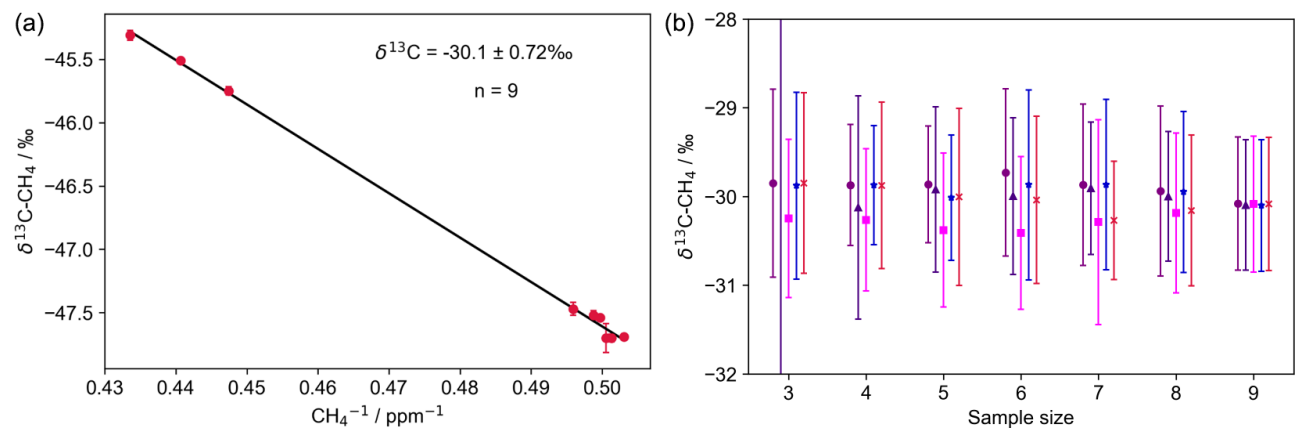

Figure 8. (a) Keeling plot determined using nine samples collected around one installation, assumed to be the single source of excess $\mathrm{CH}_{4}$. (b) An illustration of the variation in $\delta^{13} \mathrm{C}_{\mathrm{CH} 4}$ source signature and its uncertainty determined by Keeling plot analyses for reduced sample sizes. Each analysis represents a single Monte Carlo experiment with the original data, reducing the number of data points to the sample size indicated at random; the $\delta^{13} \mathrm{C}_{\mathrm{CH} 4}$ source signature is then calculated with the remaining sample points. Error bars are 2 times the standard error.

temperature structure over the previous few days using all the assimilated information, such as tephigrams and synoptic charts, would help determine the likelihood of residual boundary layers versus a simpler stratified, well-mixed layer. For methods using alternative platforms such as ships or drones, coincidental measurements of vertical profiles must be made to capture the true nature of the emission plume in the current meteorology.

Due to the size of the aircraft, payload restrictions and power limitations demand challenging decisions for instrument selection. We recommend deploying at least one instrument measuring $\mathrm{CH}_{4}$ (and $\mathrm{CO}_{2}$ ) at $10 \mathrm{~Hz}$, allowing several plumes emitted from a single installation to be resolved (Fig. 6). Priority should next be given to a $\mathrm{C}_{2} \mathrm{H}_{6}$ instrument capable of a sub-ppb limit of detection at $1 \mathrm{~Hz}$ (or higher) in order to give certainty to the source of the $\mathrm{CH}_{4}$ emission. Using $\mathrm{C} 2$ : $\mathrm{C} 1$ appears to be the simplest method for source attribution and is robust for distinguishing natural gas emissions, where the gas has an $\mathrm{C}_{2} \mathrm{H}_{6}$ component (Lowry et al., 2020; Plant et al., 2019). Spot sampling is challenging, payload heavy and time consuming, as several passes are needed to collect enough samples (especially for $\delta^{13} \mathrm{C}_{\mathrm{CH} 4}$ source attribution). However, results can be very informative, such as the ability to distinguish between a gas leak and a geological reservoir from depth or a near-surface reservoir (Lee et al., 2018). The improvements to SWAS, allowing for continuous throughflow, has increased the success rate of peak sampling but still relies on accurate user triggering.
For mass balance flux calculations, an emission plume and the surrounding background variation in the species of interest, alongside local meteorology, must be fully resolved during the observation stage. This includes instruments with appropriate response times to fully capture the plume and identify any internal structure that may suggest a mixed source. An upwind leg must be conducted to ensure the plume and background are not contaminated by extraneous far-field sources, and the plume must be significantly distinct from this background for meaningful flux calculations. The plume must be laterally and vertically resolved in the 2D plane as much as possible at a fixed distance downwind of the source. Straight and level runs must extend to either side of the plume, and the vertical resolution must include multiple stacked transects with an identification of the top and bottom of the plume (where feasible) to reduce uncertainty in the plume bulk net flux. Full understanding of the meteorology with meteorological measurement instrumentation and a complete profile to determine characteristics of the marine boundary layer from the top to the surface, including determination of inversion heights, must be conducted during the flight day when appropriate radiosonde soundings are not available. The observed impact of complex boundary layer dynamics on plume dispersion also highlights an important limitation of ship-based plume measurements, which are unable to resolve the vertical structure of the plume and therefore rely on the assumption of idealised models of plume dispersion. 


\section{Appendix A}

\section{A1 TILDAS data processing and performance}

The TILDAS data were processed as follows. Rapid tuning sweeps of the laser frequency $\left(2996.8\right.$ to $2998.0 \mathrm{~cm}^{-1}$ ) by varying the applied current result in the collection of thousands of spectra per second, which are co-averaged. The resulting averaged spectrum is processed at a rate of $1 \mathrm{~Hz}$ using a non-linear least-squares fitting algorithm to determine mixing ratios within the operating software, TDLWintel (@) Aerodyne). Averaging of these spectra and the path length of $76 \mathrm{~m}$ achieved using a Herriott multipass cell provide the sensitivity required for trace gas measurement. Continuously circulated fluid from the Oasis chiller unit is used as a heat sink for the thermodynamically cooled components, and a flow interlock cuts power to the relevant components if the coolant flow stops. Other optical components of the instrument include a $15 \times$ Schwarzschild objective in front of each laser, a germanium etalon for measuring the laser tuning rate, a reference gas cell containing air at 25 Torr and numerous mirrors for adjusting the laser beam alignment. During the airborne campaign the instrument was operated remotely via an Ethernet connection. The TILDAS $\mathrm{C}_{2} \mathrm{H}_{6}$ instrument accuracy has been tested against two standards containing $\mathrm{C}_{2} \mathrm{H}_{6}$ in mixing ratios of $39.79 \pm 0.14 \mathrm{ppb}$ and $2.08 \pm 0.02 \mathrm{ppb}$ (high-concentration standard and target gas, respectively). As the TILDAS technique relies on highly precise alignment of the focussing and beam-alignment optics before and after the multipass measurement cell, it is particularly prone to motion that applies torque to the optical bench. To remove measurement artefacts associated with this sensitivity, all data collected for roll angles greater than $20^{\circ}$ have been flagged. The presence of the TILDAS in the 2019 campaign ruled out using the multiple circular pass method around a potential emission source as developed by Scientific Aviation for installation emission flux measurements (Conley et al., 2017), as there was a risk of invalidating data due to the roll angle of the plane if circling tightly around an installation.

\section{$\mathrm{A} 2 \mathrm{CO}_{2}$ and $\mathrm{CH}_{4}$ calibration}

The three cylinders were sampled periodically in flight to determine the instrument gain factor (slope) and zero offset for each analyser. These parameters were linearly interpolated between calibrations and used to rescale the raw measured data (for further details see Pitt et al., 2016). The uncertainties associated with instrument drift and any instrument nonlinearity were assessed by sampling the target cylinder midway between high-low calibrations. The raw target cylinder measurements were rescaled as per the sample data; the mean offset of these target measurements from the WMO-traceable cylinder value (and associated standard deviations) are given for the LGR uGGA and Picarro instrument and are plotted in Fig. A4.

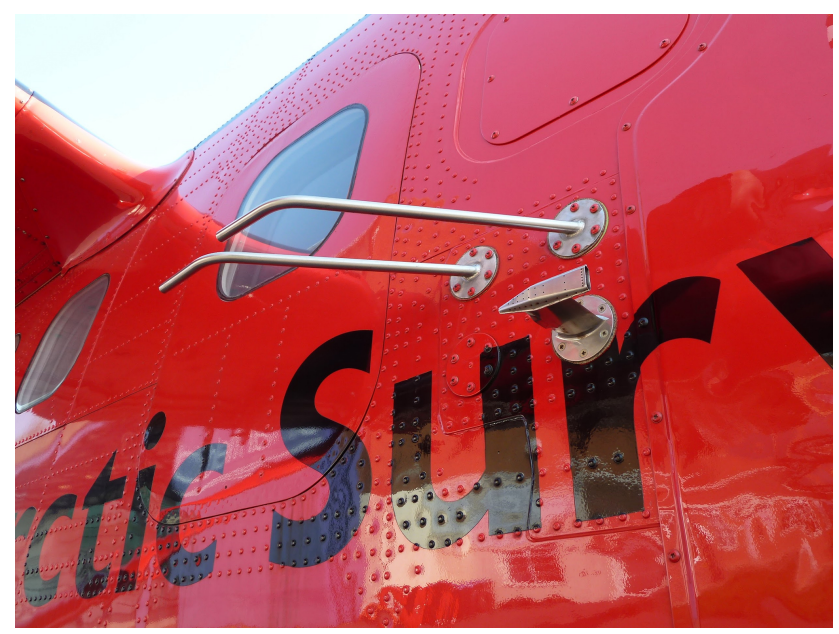

Figure A1. Photo of the rear-facing chemistry inlets on the BAS Twin Otter aircraft.

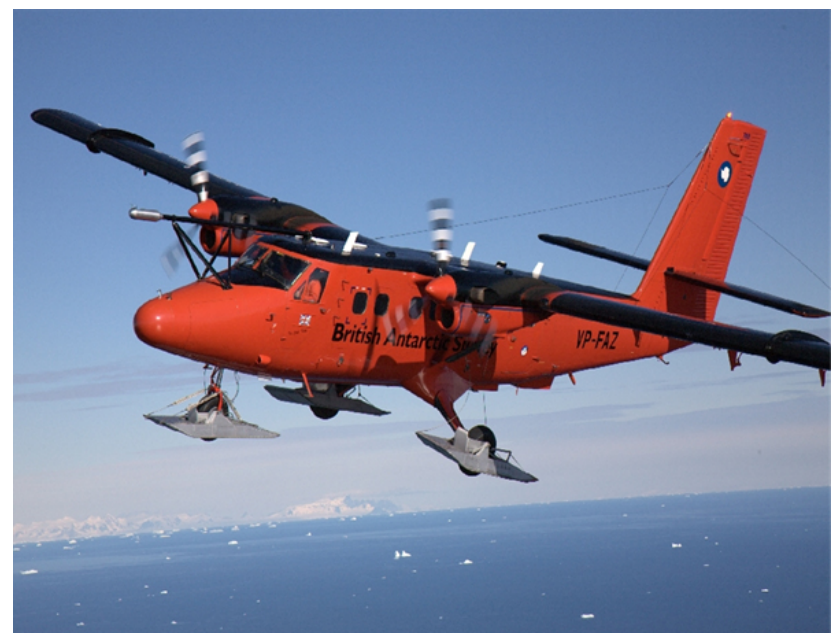

Figure A2. Photo of the BAS Twin Otter showing the turbulence boom protruding from the front of the aircraft superstructure.

The typical duration of calibration cylinder measurements during the 2018 campaign was $45 \mathrm{~s}$. The Picarro G2311-f analyser had a high flow rate of $\sim 5$ SLPM (standard litre per minute), resulting in rapid flushing of both the inlet tubing and sample cavity. The measured value for each calibration was taken as the average over $15 \mathrm{~s}$ prior to the calibration end, as this allowed sufficient time for the measured value to reach equilibrium. The uGGA and uMEA both had much lower flow rates of $\sim 0.5$ SLPM, resulting in a much longer equilibration time. Consequently, the calibration duration was not of sufficient length for the uGGA and uMEA measurements to reach equilibrium, and their calibration routine was compromised. For these instruments each calibration run was fitted to an offset exponential function in an attempt to predict the mixing ratio at which equilibration would have occurred, given an infinite amount of calibrating time. In order to im- 
Table A1. Response rates and precision for the instrument set-up on the BAS Twin Otter. All measurements were time-shifted to match the Picarro G2311-f for analysis.

\begin{tabular}{llrl}
\hline Instrument & $\begin{array}{l}\text { Measurement } \\
\text { species }\end{array}$ & $\begin{array}{r}T_{90} \\
\text { Response } \\
\text { rate }\end{array}$ & $\begin{array}{l}\text { Precision of primary } \\
\text { species of interest }\end{array}$ \\
\hline LGR uGGA & $\mathrm{CH}_{4}, \mathrm{CO}_{2}$ & $17 \mathrm{~s}$ & $\left(\mathrm{CH}_{4}\right) 1 \mathrm{ppb}$ over $10 \mathrm{~s}$ \\
Picarro G2311-F & $\mathrm{CH}_{4}, \mathrm{CO}_{2}$ & $0.4 \mathrm{~s}$ & $\left(\mathrm{CH}_{4}\right) 1.2$ ppb over $1 \mathrm{~s}$ \\
LGR uMEA & $\mathrm{C}_{2} \mathrm{H}_{6}, \mathrm{CH}_{4}$ & $17 \mathrm{~s}$ & ${ }^{\mathrm{a}}\left(\mathrm{C}_{2} \mathrm{H}_{6}\right) 17$ ppb over $1 \mathrm{~s}$ \\
TILDAS & $\mathrm{C}_{2} \mathrm{H}_{6}$ & $<2 \mathrm{~s}$ & $\mathrm{~b}\left(\mathrm{C}_{2} \mathrm{H}_{6}\right) 50$ ppt over $10 \mathrm{~s}$ \\
\hline
\end{tabular}

${ }^{a}$ Measured in laboratory. ${ }^{b}$ Manufacturer's expected precision.
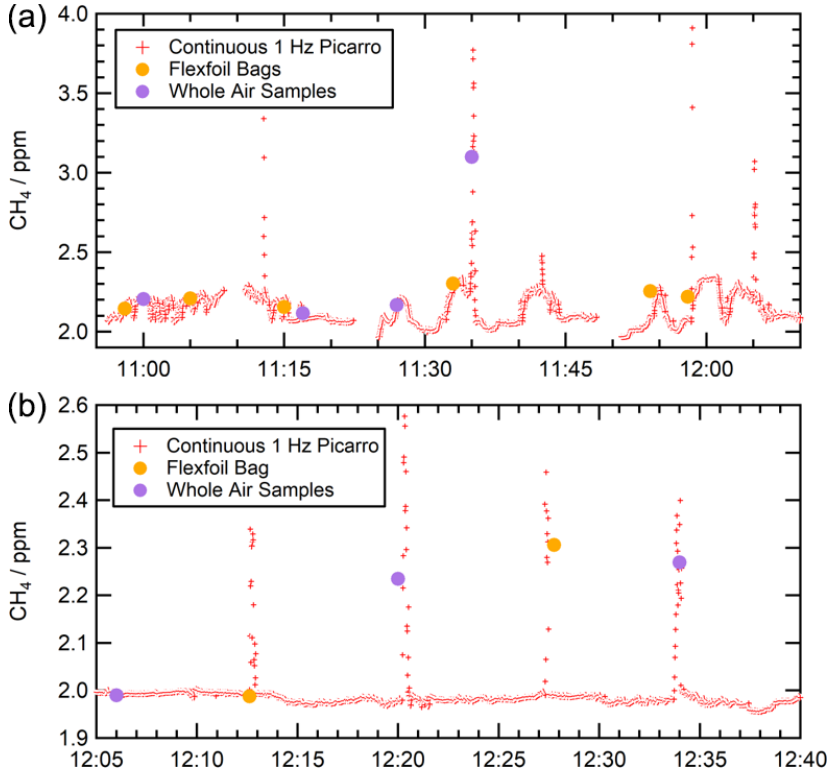

Figure A3. Examples from a 2018 flight (a) and a 2019 flight (b) with attempted capture of $\mathrm{CH}_{4}$ plumes in spot samples (both SWAS and FlexFoil bags). Note the improved ability to sample at the correct period to capture short-lived enhancement in both SWAS and FlexFoil samples for 2019 compared to 2018 thanks to flight planning and SWAS development improvements.

prove the data quality and to reduce the post processing time, the calibration periods were run for $75 \mathrm{~s}$ per cylinder during the 2019 campaign to ensure that all instruments reached equilibrium. Target cylinders were run approximately every $1 \mathrm{~h}$ of flight.

\section{A3 SWAS operation}

Each sample is compressed into the canisters using a modified metal bellows pump (Senior Aerospace 28823-7) capable of 150 SLPM open flow but filling the canisters at $\sim 50$ SLPM measured average integrated for $\sim 6$ and $9 \mathrm{~s}$ for the 1.4 and $2 \mathrm{~L}$ canisters, respectively. Canister fill pressure is controlled electronically using a back-pressure controller (Alicat PCR3; BPC). The BPC can maintain flow at any set point
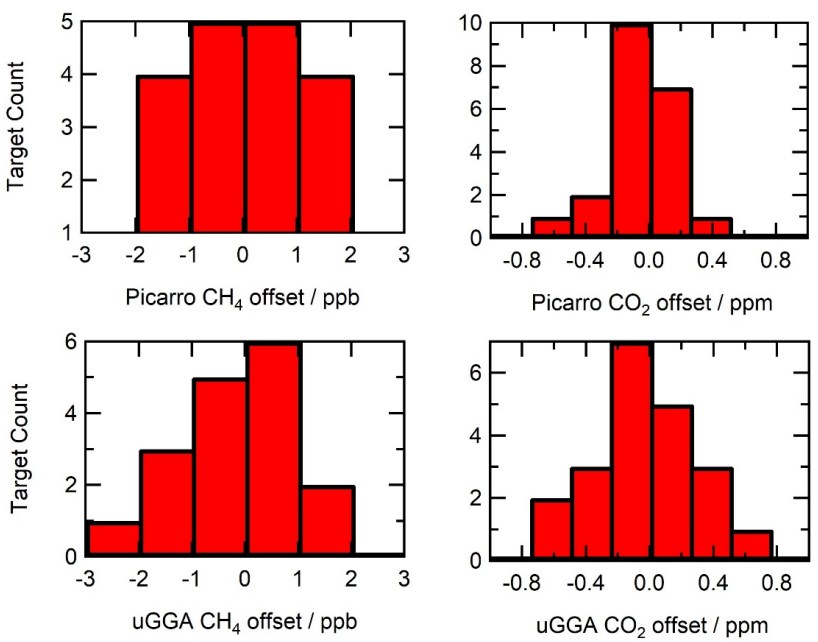

Figure A4. Target gas data from flights during 2018 for the Picarro G2311-f and Los Gatos uGGA instruments for both $\mathrm{CO}_{2}$ and $\mathrm{CH}_{4}$.

pressure (in general $40 \mathrm{psi} ; 275 \mathrm{kPa}$ ), including the final fill pressure set point. This allows the $2 \mathrm{~L}$ flow through canisters to be filled, even before the operator activates the sampling, enabling air masses to be sampled through which the aircraft has already flown seconds earlier.

Bespoke software was created to allow control of the SWAS system wirelessly from any position in the aircraft using the Ethernet network. Bespoke software was also created for the analysis of the canisters once in the laboratory. The SWAS flown on the 2018 campaign (V1) was a prototype and was updated to the current final version (V2) to fulfil the requirements of the FAAM BAe 146 and to address potential issues experienced with the prototype. V2 uses the same canisters and valves as V1 but differs slightly in the size of each case and the plumbing of gas lines. In V2, the canister and valve geometry was optimised to allow an elbow compression fitting between the valve and the canisters to be eliminated, with the valve mounted directly to the canister. This reduces the risk of leaks by $66 \%$. The geometry also allowed for the reduction in size by $1 \mathrm{U}$ rack unit, allowing for more canisters to be fitted in the same space, improved 
Table A2. Summary of VOCs measured from SWAS samples at the University of York.

\begin{tabular}{|c|c|}
\hline \multicolumn{2}{|c|}{$\begin{array}{l}\text { Volatile organic compounds identified } \\
\text { and quantified from SWAS samples }\end{array}$} \\
\hline Compound & $\begin{array}{r}\text { Detection } \\
\text { limit (ppt) }\end{array}$ \\
\hline Ethane & 4 \\
\hline Ethene & 4 \\
\hline Propane & 6 \\
\hline Propene & 2 \\
\hline iso-Butane & 1 \\
\hline n-Butane & 1 \\
\hline Acetylene & 1 \\
\hline trans-2-Butene & 2 \\
\hline but-1-Ene & 2 \\
\hline cis-2-Butene & 2 \\
\hline Cyclopentane & 2 \\
\hline iso-Butene & 2 \\
\hline iso-Pentane & 1 \\
\hline n-Pentane & 1 \\
\hline 1,3-Butadiene & 2 \\
\hline trans-2-Pentene & 2 \\
\hline pent-1-Ene & 2 \\
\hline 2,3-Methylpentanes & 2 \\
\hline n-Hexane & 2 \\
\hline Isoprene & 1 \\
\hline n-Heptane & 2 \\
\hline Benzene & 1 \\
\hline 2,2,4-Trimethylpentane & 2 \\
\hline n-Octane & 2 \\
\hline Toluene & 1 \\
\hline Ethylbenzene & 2 \\
\hline $\mathrm{m}+\mathrm{p}$-Xylenes & 2 \\
\hline o-Xylene & 2 \\
\hline
\end{tabular}

control electronics and sample logging to ensure canister fill times were captured accurately and stored securely. V2 also saw the addition of $2 \mathrm{~L}$ flow-through canister cases to complement the $1.4 \mathrm{~L}$ to-vacuum canister cases. These allowed sample air to be flushed through the canister at a user-defined pressure and makes capturing narrow plumes easier due to reduced sample line lag and fill time. 
Code and data availability. The data for this work will be available via request at the British Antarctic Survey Polar Data Centre.

Author contributions. The paper was written and figures were prepared by JF, PB and PD with assistance from AEJ, MC, JP, SB and JS. The experimental design and flight planning were performed by GA, JP, JDL, TLC and DL. Aircraft set-up and in-flight measurements were performed by JP, PB, PD, SA, SY, AW, TLC, JF, SW, JW and SB. Laboratory measurements were made by REF, RP, SW and SB. Data processing and calibrations were performed by JF, LH, PB, JS, PD, MC and SB. Modelling work was done by NW, JP, $\mathrm{PB}$ and $\mathrm{LH}$.

Competing interests. The authors declare that they have no conflict of interest.

Acknowledgements. This work was funded under the Climate \& Clean Air Coalition (CCAC) Oil and Gas Methane Science Studies (MSS) programme, hosted by the United Nations Environment Programme. Funding was provided by the Environmental Defense Fund, Oil and Gas Climate Initiative, European Commission, and CCAC.

Financial support. This research has been supported by the Climate \& Clean Air Coalition (CCAC) (grant no. DTIE18-EN018).

Review statement. This paper was edited by Pierre Herckes and reviewed by two anonymous referees.

\section{References}

Cain, M., Warwick, N. J., Fisher, R. E., Lowry, D., Lanoisellé, M., Nisbet, E. G., France, J., Pitt, J., O'Shea, S., Bower, K. N., Allen, G., Illingworth, S., Manning, A. J., Bauguitte, S., Pisso, I., and Pyle, J. A.: A cautionary tale: A study of a methane enhancement over the North Sea, J. Geophys. Res.-Atmos., 122, 7630-7645, 2017.

Cardoso-Saldaña, F. J., Kimura, Y., Stanley, P., McGaughey, G., Herndon, S. C., Roscioli, J. R., Yacovitch, T. I., and Allen, D. T.: Use of Light Alkane Fingerprints in Attributing Emissions from Oil and Gas Production, Environ. Sci. Technol., 53, 5483-5492, 2019.

Conley, S., Franco, G., Faloona, I., Blake, D. R., Peischl, J., and Ryerson, T. B.: Methane emissions from the 2015 Aliso Canyon blowout in Los Angeles, CA, Science, 351, 1317-1320, 2016.

Conley, S., Faloona, I., Mehrotra, S., Suard, M., Lenschow, D. H., Sweeney, C., Herndon, S., Schwietzke, S., Pétron, G., Pifer, J., Kort, E. A., and Schnell, R.: Application of Gauss's theorem to quantify localized surface emissions from airborne measurements of wind and trace gases, Atmos. Meas. Tech., 10, 33453358, https://doi.org/10.5194/amt-10-3345-2017, 2017.
Crawford, T. L., Dobosy, R. J., and Dumas, E. J.: Aircraft wind measurement considering lift-induced upwash, Bound.-Lay. Meteorol., 80, 79-94, 1996.

Edwards, P. M., Young, C. J., Aikin, K., deGouw, J., Dubé, W. P., Geiger, F., Gilman, J., Helmig, D., Holloway, J. S., Kercher, J., Lerner, B., Martin, R., McLaren, R., Parrish, D. D., Peischl, J., Roberts, J. M., Ryerson, T. B., Thornton, J., Warneke, C., Williams, E. J., and Brown, S. S.: Ozone photochemistry in an oil and natural gas extraction region during winter: simulations of a snow-free season in the Uintah Basin, Utah, Atmos. Chem. Phys., 13, 8955-8971, https://doi.org/10.5194/acp13-8955-2013, 2013.

Fisher, R., Lowry, D., Wilkin, O., Sriskantharajah, S., and Nisbet, E. G.: High-precision, automated stable isotope analysis of atmospheric methane and carbon dioxide using continuous-flow isotope-ratio mass spectrometry, Rap. Commun. Mass Spectro., 20, 200-208, 2006.

Fisher, R. E., France, J. L., Lowry, D., Lanoisellé, M., Brownlow, R., Pyle, J. A., Cain, M., Warwick, N., Skiba, U. M., Drewer, J., Dinsmore, K. J., Leeson, S. R., Bauguitte, S. J.-B., Wellpott, A., O'Shea, S. J., Allen, G., Gallagher, M. W., Pitt, J., Percival, C. J., Bower, K., George, C., Hayman, G. D., Aalto, T., Lohila, A., Aurela, M., Laurila, T., Crill, P. M., McCalley, C. K., and Nisbet, E. G.: Measurement of the $13 \mathrm{C}$ isotopic signature of methane emissions from northern European wetlands, Global Biogeochem. Cy., 31, 605-623, 2017.

Garman, K. E., Hill, K. A., Wyss, P., Carlsen, M., Zimmerman, J. R., Stirm, B. H., Carney, T. Q., Santini, R., and Shepson, P. B.: An Airborne and Wind Tunnel Evaluation of a Wind Turbulence Measurement System for Aircraft-Based Flux Measurements, J. Atmos. Ocean. Technol., 23, 1696-1708, 2006.

Garman, K. E., Wyss, P., Carlsen, M., Zimmerman, J. R., Stirm, B. H., Carney, T. Q., Santini, R., and Shepson, P. B.: The Contribution of Variability of Lift-induced Upwash to the Uncertainty in Vertical Winds Determined from an Aircraft Platform, Bound.Lay. Meteorol., 126, 461-476, 2008.

Gorchov Negron, A. M., Kort, E. A., Conley, S. A., and Smith, M. L.: Airborne Assessment of Methane Emissions from Offshore Platforms in the U.S. Gulf of Mexico, Environ. Sci. Technol., 54, 5112-5120, 2020.

Gvakharia, A., Kort, E. A., Brandt, A., Peischl, J., Ryerson, T. B., Schwarz, J. P., Smith, M. L., and Sweeney, C.: Methane, Black Carbon, and Ethane Emissions from Natural Gas Flares in the Bakken Shale, North Dakota, Environ. Sci. Technol., 51, 53175325, 2017.

Gvakharia, A., Kort, E. A., Smith, M. L., and Conley, S.: Testing and evaluation of a new airborne system for continuous $\mathrm{N}_{2} \mathrm{O}, \mathrm{CO}_{2}, \mathrm{CO}$, and $\mathrm{H}_{2} \mathrm{O}$ measurements: the Frequent Calibration High-performance Airborne Observation System (FCHAOS), Atmos. Meas. Tech., 11, 6059-6074, https://doi.org/10.5194/amt-11-6059-2018, 2018.

Hopkins, J. R., Lewis, A. C., and Read, K. A.: A two-column method for long-term monitoring of non-methane hydrocarbons (NMHCs) and oxygenated volatile organic compounds (oVOCs), J. Environ. Monit., 5, 8-13, 2003.

Johnson, M. R., Tyner, D. R., Conley, S., Schwietzke, S., and Zavala-Araiza, D.: Comparisons of Airborne Measurements and Inventory Estimates of Methane Emissions in the Alberta Up- 
stream Oil and Gas Sector, Environ. Sci. Technol., 51, 1300813017, 2017.

Jones, A., Thomson, D., Hort, M., and Devenish, B.: The U.K. Met Office's Next-Generation Atmospheric Dispersion Model, NAME III, Boston, MA2007, 580-589, 2007.

Keeling, C. D.: The concentration and isotopic abundances of carbon dioxide in rural and marine air, Geochim. Cosmochim. Acta, 24, 277-298, 1961.

Kostinek, J., Roiger, A., Davis, K. J., Sweeney, C., DiGangi, J. P., Choi, Y., Baier, B., Hase, F., Groß, J., Eckl, M., Klausner, T., and Butz, A.: Adaptation and performance assessment of a quantum and interband cascade laser spectrometer for simultaneous airborne in situ observation of $\mathrm{CH}_{4}, \mathrm{C}_{2} \mathrm{H}_{6}, \mathrm{CO}_{2}, \mathrm{CO}$ and $\mathrm{N}_{2} \mathrm{O}$, Atmos. Meas. Tech., 12, 1767-1783, https://doi.org/10.5194/amt12-1767-2019, 2019.

Lee, J. D., Mobbs, S. D., Wellpott, A., Allen, G., Bauguitte, S. J.B., Burton, R. R., Camilli, R., Coe, H., Fisher, R. E., France, J. L., Gallagher, M., Hopkins, J. R., Lanoiselle, M., Lewis, A. C., Lowry, D., Nisbet, E. G., Purvis, R. M., O'Shea, S., Pyle, J. A., and Ryerson, T. B.: Flow rate and source reservoir identification from airborne chemical sampling of the uncontrolled Elgin platform gas release, Atmos. Meas. Tech., 11, 1725-1739, https://doi.org/10.5194/amt-11-1725-2018, 2018.

Lowry, D., Fisher, R. E., France, J. L., Coleman, M., Lanoisellé, M., Zazzeri, G., Nisbet, E. G., Shaw, J. T., Allen, G., Pitt, J., and Ward, R. S.: Environmental baseline monitoring for shale gas development in the UK: Identification and geochemical characterisation of local source emissions of methane to atmosphere, Sci. Total Environ., 708, 134600, https://doi.org/10.1016/j.scitotenv.2019.134600, 2020.

Milan, M., Macpherson, B., Tubbs, R., Dow, G., Inverarity, G., Mittermaier, M., Halloran, G., Kelly, G., Li, D., Maycock, A., Payne, T., Piccolo, C., Stewart, L., and Wlasak, M.: Hourly 4D-Var in the Met Office UKV operational forecast model, Q. J. Roy. Meteorol. Soc., 146, 1-21, https://doi.org/10.1002/qj.3737, 2020.

Myhre, G., Shindell, D., Breìn, F.-M., Collins, W., Fuglestvedt, J., Huang, J., Koch, D., Lamarque, J.-F., Lee, D., Mendoza, B., Nakajima, T., Robock, A., Stephens, G., Takemura, T., and Zhang, H.: Anthropogenic and Natural Radiative Forcing, in: Climate Change 2013: The Physical Science Basis. Contribution of Working Group I to the Fifth Assessment Report of the Intergovernmental Panel on Climate Change, edited by: Stocker, T. F., Qin, D., Plattner, G.-K., Tignor, M., Allen, S. K., Boschung, J., Nauels, A., Xia, Y., Bex, V., and Midgley, P. M., Cambridge University Press, Cambridge, United Kingdom and New York, NY, USA, 2013.

Nelson, D. D., McManus, B., Urbanski, S., Herndon, S., and Zahniser, M. S.: High precision measurements of atmospheric nitrous oxide and methane using thermoelectrically cooled midinfrared quantum cascade lasers and detectors, Spectrochim. Acta A-M, 60, 3325-3335, 2004.

Nisbet, E. G., Manning, M. R., Dlugokencky, E. J., Fisher, R. E., Lowry, D., Michel, S. E., Myhre, C. L., Platt, S. M., Allen, G., Bousquet, P., Brownlow, R., Cain, M., France, J. L., Hermansen, O., Hossaini, R., Jones, A. E., Levin, I., Manning, A. C., Myhre, G., Pyle, J. A., Vaughn, B. H., Warwick, N. J., and White, J. W. C.: Very Strong Atmospheric Methane Growth in the 4 Years 2014-2017: Implications for the Paris Agreement, Global Biogeochem. Cy., 33, 318-342, 2019.
O'Shea, S. J., Allen, G., Gallagher, M. W., Bower, K., Illingworth, S. M., Muller, J. B. A., Jones, B. T., Percival, C. J., Bauguitte, S. J.-B., Cain, M., Warwick, N., Quiquet, A., Skiba, U., Drewer, J., Dinsmore, K., Nisbet, E. G., Lowry, D., Fisher, R. E., France, J. L., Aurela, M., Lohila, A., Hayman, G., George, C., Clark, D. B., Manning, A. J., Friend, A. D., and Pyle, J.: Methane and carbon dioxide fluxes and their regional scalability for the European Arctic wetlands during the MAMM project in summer 2012, Atmos. Chem. Phys., 14, 13159-13174, https://doi.org/10.5194/acp-14-13159-2014, 2014.

O'Shea, S. J., Bauguitte, S. J.-B., Gallagher, M. W., Lowry, D., and Percival, C. J.: Development of a cavity-enhanced absorption spectrometer for airborne measurements of $\mathrm{CH}_{4}$ and $\mathrm{CO}_{2}$, Atmos. Meas. Tech., 6, 1095-1109, https://doi.org/10.5194/amt6-1095-2013, 2013.

Pataki, D. E., Ehleringer, J. R., Flanagan, L. B., Yakir, D., Bowling, D. R., Still, C. J., Buchmann, N., Kaplan, J. O., and Berry, J. A.: The application and interpretation of Keeling plots in terrestrial carbon cycle research, Global Biogeochem. Cy., 17, 1022, https://doi.org/10.1029/2001GB001850, 2003.

Peischl, J., Eilerman, S. J., Neuman, J. A., Aikin, K. C., de Gouw, J., Gilman, J. B., Herndon, S. C., Nadkarni, R., Trainer, M., Warneke, C., and Ryerson, T. B.: Quantifying Methane and Ethane Emissions to the Atmosphere From Central and Western U.S. Oil and Natural Gas Production Regions, J. Geophys. Res.-Atmos., 123, 7725-7740, 2018.

Pitt, J. R., Le Breton, M., Allen, G., Percival, C. J., Gallagher, M. W., Bauguitte, S. J.-B., O'Shea, S. J., Muller, J. B. A., Zahniser, M. S., Pyle, J., and Palmer, P. I.: The development and evaluation of airborne in situ $\mathrm{N} 2 \mathrm{O}$ and $\mathrm{CH} 4$ sampling using a quantum cascade laser absorption spectrometer (QCLAS), Atmos. Meas. Tech., 9, 63-77, https://doi.org/10.5194/amt-9-63-2016, 2016.

Pitt, J. R., Allen, G., Bauguitte, S. J.-B., Gallagher, M. W., Lee, J. D., Drysdale, W., Nelson, B., Manning, A. J., and Palmer, P. I.: Assessing London $\mathrm{CO} 2, \mathrm{CH} 4$ and $\mathrm{CO}$ emissions using aircraft measurements and dispersion modelling, Atmos. Chem. Phys., 19, 8931-8945, https://doi.org/10.5194/acp-198931-2019, 2019.

Plant, G., Kort, E. A., Floerchinger, C., Gvakharia, A., Vimont, I., and Sweeney, C.: Large Fugitive Methane Emissions From Urban Centers Along the U.S. East Coast, Geophys. Res. Lett., 46, 8500-8507, 2019.

Rella, C. W., Hoffnagle, J., He, Y., and Tajima, S.: Local- and regional-scale measurements of $\mathrm{CH}_{4}, \delta^{13} \mathrm{CH}_{4}$, and $\mathrm{C}_{2} \mathrm{H}_{6}$ in the Uintah Basin using a mobile stable isotope analyzer, Atmos. Meas. Tech., 8, 4539-4559, https://doi.org/10.5194/amt-8-45392015, 2015.

Riddick, S. N., Mauzerall, D. L., Celia, M., Harris, N. R. P., Allen, G., Pitt, J., Staunton-Sykes, J., Forster, G. L., Kang, M., Lowry, D., Nisbet, E. G., and Manning, A. J.: Methane emissions from oil and gas platforms in the North Sea, Atmos. Chem. Phys., 19, 9787-9796, https://doi.org/10.5194/acp-19-9787-2019, 2019.

Ryerson, T. B., Camilli, R., Kessler, J. D., Kujawinski, E. B., Reddy, C. M., Valentine, D. L., Atlas, E., Blake, D. R., de Gouw, J., Meinardi, S., Parrish, D. D., Peischl, J., Seewald, J. S., and Warneke, C.: Chemical data quantify Deepwater Horizon hydrocarbon flow rate and environmental distribution, P. Natl. Acad. Sci. USA, 109, 20246-20253, 2012. 
Santoni, G. W., Daube, B. C., Kort, E. A., Jiménez, R., Park, S., Pittman, J. V., Gottlieb, E., Xiang, B., Zahniser, M. S., Nelson, D. D., McManus, J. B., Peischl, J., Ryerson, T. B., Holloway, J. S., Andrews, A. E., Sweeney, C., Hall, B., Hintsa, E. J., Moore, F. L., Elkins, J. W., Hurst, D. F., Stephens, B. B., Bent, J., and Wofsy, S. C.: Evaluation of the airborne quantum cascade laser spectrometer (QCLS) measurements of the carbon and greenhouse gas suite $-\mathrm{CO}_{2}, \mathrm{CH}_{4}, \mathrm{~N}_{2} \mathrm{O}$, and $\mathrm{CO}$ - during the CalNex and HIPPO campaigns, Atmos. Meas. Tech., 7, 1509-1526, https://doi.org/10.5194/amt-7-1509-2014, 2014.

Saunois, M., Bousquet, P., Poulter, B., Peregon, A., Ciais, P., Canadell, J. G., Dlugokencky, E. J., Etiope, G., Bastviken, D., Houweling, S., Janssens-Maenhout, G., Tubiello, F. N., Castaldi, S., Jackson, R. B., Alexe, M., Arora, V. K., Beerling, D. J., Bergamaschi, P., Blake, D. R., Brailsford, G., Brovkin, V., Bruhwiler, L., Crevoisier, C., Crill, P., Covey, K., Curry, C., Frankenberg, C., Gedney, N., Höglund-Isaksson, L., Ishizawa, M., Ito, A., Joos, F., Kim, H.-S., Kleinen, T., Krummel, P., Lamarque, J.-F., Langenfelds, R., Locatelli, R., Machida, T., Maksyutov, S., McDonald, K. C., Marshall, J., Melton, J. R., Morino, I., Naik, V., O'Doherty, S., Parmentier, F.-J. W., Patra, P. K., Peng, C., Peng, S., Peters, G. P., Pison, I., Prigent, C., Prinn, R., Ramonet, M., Riley, W. J., Saito, M., Santini, M., Schroeder, R., Simpson, I. J., Spahni, R., Steele, P., Takizawa, A., Thornton, B. F., Tian, H., Tohjima, Y., Viovy, N., Voulgarakis, A., van Weele, M., van der Werf, G. R., Weiss, R., Wiedinmyer, C., Wilton, D. J., Wiltshire, A., Worthy, D., Wunch, D., Xu, X., Yoshida, Y., Zhang, B., Zhang, Z., and Zhu, Q.: The global methane budget 2000-2012, Earth Syst. Sci. Data, 8, 697-751, https://doi.org/10.5194/essd-8-697-2016, 2016.

Schwietzke, S., Harrison, M., Lauderdale, T., Branson, K., Conley, S., George, F. C., Jordan, D., Jersey, G. R., Zhang, C., Mairs, H. L., Pétron, G., and Schnell, R. C.: Aerially guided leak detection and repair: A pilot field study for evaluating the potential of methane emission detection and cost-effectiveness, J. Air Waste Manage. Assoc., 69, 71-88, 2019.

Sherwood, O. A., Schwietzke, S., Arling, V. A., and Etiope, G.: Global Inventory of Gas Geochemistry Data from Fossil Fuel, Microbial and Burning Sources, version 2017, Earth Syst. Sci. Data, 9, 639-656, https://doi.org/10.5194/essd-9-639-2017, 2017.

Stull, R. B.: An Introduction to Boundary Layer Meteorology, Springer, Netherlands, https://doi.org/10.1007/978-94-0093027-8, 1988.
Warneke, C., Trainer, M., de Gouw, J. A., Parrish, D. D., Fahey, D. W., Ravishankara, A. R., Middlebrook, A. M., Brock, C. A., Roberts, J. M., Brown, S. S., Neuman, J. A., Lerner, B. M., Lack, D., Law, D., Hübler, G., Pollack, I., Sjostedt, S., Ryerson, T. B., Gilman, J. B., Liao, J., Holloway, J., Peischl, J., Nowak, J. B., Aikin, K. C., Min, K.-E., Washenfelder, R. A., Graus, M. G., Richardson, M., Markovic, M. Z., Wagner, N. L., Welti, A., Veres, P. R., Edwards, P., Schwarz, J. P., Gordon, T., Dube, W. P., McKeen, S. A., Brioude, J., Ahmadov, R., Bougiatioti, A., Lin, J. J., Nenes, A., Wolfe, G. M., Hanisco, T. F., Lee, B. H., LopezHilfiker, F. D., Thornton, J. A., Keutsch, F. N., Kaiser, J., Mao, J., and Hatch, C. D.: Instrumentation and measurement strategy for the NOAA SENEX aircraft campaign as part of the Southeast Atmosphere Study 2013, Atmos. Meas. Tech., 9, 3063-3093, https://doi.org/10.5194/amt-9-3063-2016, 2016.

Weiss, A. I., King, J., Lachlan-Cope, T., and Ladkin, R.: On the effective aerodynamic and scalar roughness length of Weddell Sea ice, J. Geophys. Res.-Atmos., 116, D19119, https://doi.org/10.1029/2011JD015949, 2011.

Yacovitch, T. I., Herndon, S. C., Roscioli, J. R., Floerchinger, C., McGovern, R. M., Agnese, M., Pétron, G., Kofler, J., Sweeney, C., Karion, A., and Conley, S. A.: Demonstration of an ethane spectrometer for methane source identification, Environ. Sci Technol., 48, 8028, https://doi.org/10.1021/es501475q, 2014a.

Yacovitch, T. I., Herndon, S. C., Roscioli, J. R., Floerchinger, C., McGovern, R. M., Agnese, M., Pétron, G., Kofler, J., Sweeney, C., Karion, A., Conley, S. A., Kort, E. A., Nähle, L., Fischer, M., Hildebrandt, L., Koeth, J., McManus, J. B., Nelson, D. D., Zahniser, M. S., and Kolb, C. E.: Demonstration of an Ethane Spectrometer for Methane Source Identification, Environ. Sci. Technol., 48, 8028-8034, 2014b.

Yacovitch, T. I., Neininger, B., Herndon, S. C., van der Gon, H. D., Jonkers, S., Hulskotte, J., Roscioli, J. R., and Zavala-Araiza, D.: Methane emissions in the Netherlands: The Groningen field, Elementa: Sci. Anthrop. 6, 57, https://doi.org/10.1525/elementa.308, 2018.

Yacovitch, T. I., Daube, C., and Herndon, S. C.: Methane Emissions from Offshore Oil and Gas Platforms in the Gulf of Mexico, Environ. Sci. Technol., 54, 3530-3538, 2020.

Zavala-Araiza, D., Alvarez, R. A., Lyon, D. R., Allen, D. T., Marchese, A. J., Zimmerle, D. J., and Hamburg, S. P.: Super-emitters in natural gas infrastructure are caused by abnormal process conditions, Nat. Commun., 8, 14012, https://doi.org/10.1038/ncomms14012, 2017. 